\title{
江南世界级铇矿带: 地质特征、成矿规律和矿床模型
}

毛景文 ${ }^{1,2^{*}}$, 吴胜华 ${ }^{1}$, 宋世伟 ${ }^{1}$, 戴盼 ${ }^{3}$, 谢桂青 ${ }^{1}$, 苏蓄薇 ${ }^{1}$, 刘鹏 ${ }^{4}$, 王先 $广^{5}$, 余忠珍 ${ }^{6}$, 陈祥云 ${ }^{6}$, 唐维新 ${ }^{6}$

1. 中国地质科学院矿产资源研究所, 自然资源部成矿作用与资源评价重点实验室, 北京 100037;

2. 河北地质大学地球科学学院, 石家庄 050031 ;

3. 山东理工大学资源与环境工程学院, 淄博 255000 ;

4. 长安大学地球科学与资源学院, 西安 710054;

5. 江西省地质勘查基金管理中心, 南昌 330025;

6. 江西省地质矿产勘查开发局, 南昌 330002

*联系人, E-mail: jingwenmao@263.net

2020-04-04 收稿, 2020-07-20 修回, 2020-07-20 接受, 2020-07-28 网络版发表

国家自然科学基金重点项目(41430314)资助

摘要 江南铇矿带是过去 10 年以来确定的一个世界级铇矿带, 探明资源量达 606 万 $\mathrm{t}$, 而且具有很好的进一步找矿潜 力. 通过对该铇矿带的时空分布规律研究，确立了位于扬子地块东南缘江南古陆及东延地区的江南铇矿带与其北 邻的长江中下游斑岩-矽卡岩型铜-金-钼-铁成矿带在空间上平行分布，具有相同的成矿时间段，即150 135和 130 125 Ma两期成矿. 这些矿床的基本特点是围绕花岗岩体内外接触带发育, 其外围或者上部发育有脉状铅锌或 者铜铅锌矿. 在矿带除了东坪石英脉型铇矿外, 其余均是斑岩和矽卡岩型矿床, 尤其是朱溪矽卡岩型铇矿探明资源 量 344 万 $\mathrm{t}$, 为全球最大铇矿, 而大湖塘超大型、东源和阳储岭大型斑岩铇矿的探明改变了世界铇矿类型的格局, 即 斑岩型、矽卡岩型和石英脉型成为全球三大铇矿类型. 按照与成矿有关花岗岩类的性质, 可以分为与高分异还原 性S型黑云母二长花岗岩有关和与氧化性I型花岗闪长岩有关的铇矿床, 前者往往形成超大型矿床。研究提出该铇 矿带两期铇矿分别是古太平洋板块俯冲和后俯冲过程的产物, 并给出成矿动力学模型. 研究认为地壳泥质岩石重 熔形成的花岗岩浆上侵定位, 部分岩浆源区含基性-超基性岩夹层抑或在形成过程有地幔物质加入, 经过高分异演 化, 在岩浆房隆起部位的内外接触带成矿。考虑到岩浆和围岩性质、含矿流体成矿过程和矿化蚀变特点提出了矿 带的矿床模型, 并对该矿带进一步找矿给出了一些思考.

关键词铇矿床, 斑岩-矽卡岩型, 成矿规律, 矿床模型

铇在国际上称为稀有金属，在我国列为黑色金属. 铇通常用于照明、冶金和医疗器械, 近些年随着高科 技的开发和利用，铇金属用途日益广泛. 例如，手机振 子、深井钻头和高强刀具等, 尤其是武器制造方面的 广泛应用，例如，装甲车、穿甲弹、防弹车、装甲坦 克、大炮部件等. 由铇合金制造的动能穿甲弹可以与
贫铀弹媲美. 铇是我国优势矿产, 过去长期以来已探明 铇矿主要分布于南岭地区.

从全球角度来看, 铇矿床主要类型有矽卡岩型和 黑铇矿-石英脉型，次要类型有斑岩型、云英岩型、角 砾岩型、蚀变花岗岩型和铇-锑-金低温热液脉型. 长期 以来前两种类型矿床曾占已探明铇资源量的 $90 \%$ 以上.

引用格式: 毛景文, 吴胜华, 宋世伟, 等. 江南世界级铇矿带: 地质特征、成矿规律和矿床模型. 科学通报, 2020, 65: 3746-3762

Mao J W, Wu S H, Song S W, et al. The world-class Jiangnan tungsten belt: Geological characteristics, metallogeny, and ore deposit model (in Chinese). Chin Sci Bull, 2020, 65: 3746-3762, doi: 10.1360/TB-2020-0370 
但是，最近几年在我国长江中下游地区南侧的江南古 陆及邻区发现和探明了一批斑岩-矽卡岩型铇矿床，构 成了一个与长江中下游铜多金属矿带相平行的铇矿带 (简称为江南铇矿带). 迄今为止，在该矿带探明铇资源 量近606万 $\mathrm{t}($ 表 $\mathrm{S} 1)$, 其中大湖塘的铇资源量为 107 万 $\mathrm{t}^{[1,2]}$, 朱溪矽卡岩型铇矿的铇资源量为 344 万 $\mathrm{t}^{[3,4]}$. 该铇矿带 的发现和探明在全球具有重要的冲击作用, 改变了过 去对于铇矿的某些认知: 其一, 斑岩铇矿成为全球另外 一种重要的矿床类型; 其二, 重塑了我国铇矿空间分布 的格局，即南岭地区不再是我国或全球唯一超大型铇 富集区，江南铇矿带为另一个超大型铇富集区; 其三, 江南铇矿带与北侧的长江中下游斑岩-矽卡岩型铜多 金属矿带平行分布, 成矿时代基本相同, 表明了两个矿 带的形成具有同样成矿动力学背景, 在成因上具有一 定的内在联系. 本文基于前人工作基础和科研团队近 10年的工作积累，对江南铇矿带的成矿地质特征、成 矿规律和矿床模型进行总结研究.

\section{1 区域成矿背景}

如上所述, 江南斑岩-矽卡岩型铇矿带与长江中下 游斑岩-矽卡岩型铜多金属成矿带在空间上平行分布 (图1). 后者位于扬子地块北缘, 襄栎-广济和郯城-庐江 大断裂位于其北缘; 南界的阳新-常州断裂带将其与扬 子地块其他部分(主要为江南古陆)分开(图1). 江南铇 矿带位于江南古陆及其东延部分, 其南侧边界为钦杭 新元古代缝合带. 江南古陆及邻区出露的地层为前寒 武纪基底和显生宙盖层. 在阳新-常州断裂以南的前寒 武纪基底为中元古代田里片岩、早新元古代双溪坞 火山碎屑岩和中新元古代沉积岩以及江南古陆东部 蛇绿岩 ${ }^{[6 ~ 10]}$. 在江南古陆中部的新元古代沉积岩包括 双桥山群千枚岩和变火山沉积岩, 向上粒度变粗, 局 部保留原始沉积结构. 过去10多年研究表明双桥山群 形成时代为 830 $\mathrm{Ma}^{[7,9]}$, 也基本代表了江南造山带的 形成时代. 最晚期的新元古代南华群沉积在造山后的 伸展盆地，不整合地覆盖在前寒武纪基底之上. 上覆 的显生宙沉积岩围绕江南古陆沉积, 包括志留系到下 三叠统海相碎屑岩和碳酸盐岩、中三叠统至上侏罗 统近海陆相碎屑岩、中-晚侏罗统沉积岩和火山岩, 以 及一系列NE向陆相断陷盆地中的白严系红层砂岩. 尚 未见有中-晚侏罗世安山质火山岩的精确测年资料, 但 其同源的次火山岩、花岗闪长岩的锆石 $\mathrm{U}-\mathrm{Pb}$ 年龄为 $172 \sim 170 \mathrm{Ma}^{[11,12]}$.
研究区内广泛发育有新元古代和晚中生代花岗质 侵人体. 新元古代九岭花岗岩闪长岩基( $828 \pm 8 \mathrm{Ma})$ 为华 南地区的最大岩基 ${ }^{[13]}$, 侵人到双桥山群千枚岩中. 在皖 南还出现有许村、㰸县和休宁几个新元古代岩体 ${ }^{[14]}$. 在长江中下游有 3 种类型侵入体 ${ }^{[15]}$. 第一类为高钾钻碱 性或者I型花岗岩(或者磁铁矿系列), 包括闪长岩、石 英闪长岩和花岗闪长岩 ${ }^{[15,16]}$. 这套岩石与斑岩-矽卡岩 型铜-金-钿-铁矿床具有密切的成因联系，成岩时代为 156 137 $\mathrm{Ma}^{[17]}$. 第二类出现于白严纪火山沉积盆地, 包括富辉石闪长玢岩和正长花岗斑岩以及同源火山岩, 成岩时代为 $135 \sim 123 \mathrm{Ma}^{[17]}$. 第三类是 $A$ 型花岗岩类, 与 $\mathrm{Au} 、 \mathrm{U}$ 和 $\mathrm{Pb}-\mathrm{Zn}$ 矿化有关 ${ }^{[18]}$. 在长江中下游以南的江南 古陆及东延地区广泛发育大量燕山期花岗岩类，包括 黑云母二长花岗岩、石英二长岩、花岗闪长岩, 以及 少量碱性花岗岩和石英正长岩, 与铇矿及少量锡矿具 有密切的成因关系，成岩时代有两个时间段，分别为 152 138和129 127 Ma(表S1, 图S1).

碎屑锆石U-Pb测年表明江南古陆最老年龄不超过 10 亿年 ${ }^{[19]}$, 在1.0 0.87 Ga期间古华南洋开始向北俯冲, 导致在江南古陆南缘成为活动大陆边缘, 并沿江绍断 裂带出现蛇绿混杂岩带、德兴蓝片岩和浙东-赣北I型 花岗岩带, 大致标定了碰撞拼接位置 ${ }^{[20-22]}$, 并在朱溪铇 矿区南侧发现大陆弧环境的斑岩铜矿化, 其时代为 $0.847 \mathrm{Ga}^{[23]}$ ). 除此之外, 沿江南古陆南缘广泛分布的 后碰撞过铝质高分异花岗岩，在桂北地区沿这套岩体 接触带发育有一系列锡矿床 ${ }^{[24]}$. 稍后, 出现大陆裂解, 以基性岩墙、双峰式侵人岩和大陆裂谷盆地为标志, 年龄峰值为 $0.8 \sim 0.7 \mathrm{Ga}^{[25]}$. 接着在江南古陆南北两个海 槽内发育有震旦纪至早三叠世海相沉积岩, 其中由于 广西运动(可能是澳大利亚大陆与华南地块碰撞对接 所引致)导致华南隆升而缺失上志留统至中下泥盆统, 直到中晚三叠世古特提斯大洋闭合, 华南地块与华北 克拉通碰撞对接, 形成了统一的欧亚大陆. 大约在 170 Ma， Izanagi或者古太平洋板片向大陆NW向斜俯冲 ${ }^{[26]}$, 在包括江南古陆的中国东部广泛发育 NE向压扭性断 裂及褶皱. 由于板块后撤或者转向导致大陆出现大规 模持续伸展，由此形成了中国东部与俯冲和后俯冲有 关的两次大规模成岩成矿事件 ${ }^{[27,28]}$.

\section{2 江南铇矿带的地质特征}

江南铇矿带走向近E向或者NEE向, 在2000年之前, 该带仅探明几个铇锡矿，即在赣西北地区的阳储岭铇 


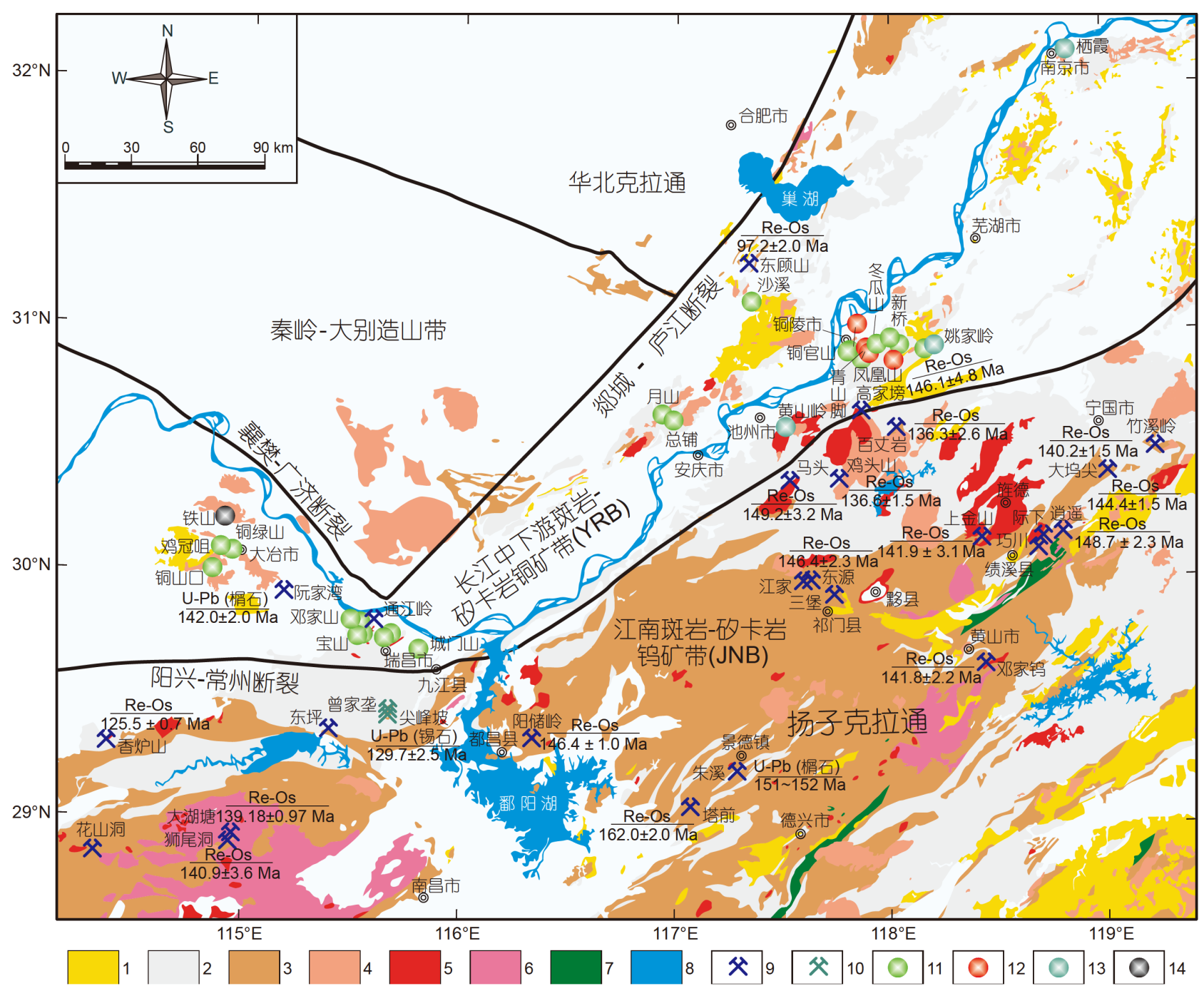

图 1 江南铇矿带地质与铇矿分布图 ${ }^{[5]}$. 1, 中侏罗统至白严系沉积岩和火山岩; 2 , 寒武系至下三叠统层状海相碎屑岩和碳酸盐岩, 中三叠统至 上三叠统近海相碎屑岩; 3 , 江南古陆: 新元古代浅变质岩及沉积岩; 4 , 白严纪中酸性侵人体; 5 , 侏罗纪中酸性侵人体; 6 , 新元古代中酸性侵人体; 7 , 新元古代蛇绿岩; 8 , 河流湖泊; 9 , 铇矿床; 10 , 锡矿床; 11 , 铜矿床; 12 , 金矿床; 13 , 铅锌矿床; 14 , 铁矿床

Figure 1 Simplified geological map of the Jiangnan $\mathrm{W}$ ore belt, showing the distribution of the $\mathrm{W}$ deposits ${ }^{[5]}$. 1, Middle Jurassic to Cretaceous sedimentary and volcanic rocks; 2, Cambrian to Early Triassic marine clastic and carbonate rocks, and Middle Triassic to Early Jurassic paralic clastic rocks; 3, Jiangnan Massif: Neoproterozoic epimetamorphic and sedimentary rocks; 4, Cretaceous granitoids; 5, Jurassic granitoids; 6, Neoproterozoic granite; 7, Neoproterozoic ophiolite; 8, river and lake; 9, W deposit; 10, Sn deposit; 11, Cu deposit; 12, Au deposit; 13, Pb-Zn deposit; 14, Fe deposit

矿、香炉山铇矿、曾家垄和尖峰坡锡矿。过去10多年 又探明了一批铇矿(表S1), 包括贑北的朱溪和大湖塘世 界级铇矿、东坪大型铇矿，皖南东源铇-钿、上金山 铇、际下铇、逍遥铇、竹溪岭铇、邓家坞钿-铇、鸡 头山铇-钿、高家塝铇-钿、马头铇-钿以及三堡铇-铜铅-锌矿, 这些矿床的主要地质特征列于表S1。斑岩和 矽卡岩是成矿带内最主要矿床类型, 前者包括大湖 塘、阳储岭和东源，后者包括朱溪、香炉山、竹溪 岭、逍遥、三堡、上金山、邓家坞、百丈岩、高家 塝、鸡头山、马头、大坞尖和巧川, 其次是石英脉型,
仅有新近探明的东坪大型铇矿 ${ }^{[29,30]}$. 此外, 石英脉型通 常作为一种次要类型出现在大湖塘、上金山和大坞尖 等矿区. 按照探明的资源量, 江南铇矿带中超大型铇矿 有朱溪和大湖塘, 其资源量和品位分别为 $3.44 \mathrm{Mt} / 0.5 \%$ 和 $1.07 \mathrm{Mt} / 0.15 \%$. 大型铇矿有香炉山、东源、阳储 岭、竹溪岭、东坪、道遥和高家塝, 其余为中小型, 铇 矿的矿石吨位和品位示于图2. 曾家垄为区内仅有的大 型锡矿, 已探明锡资源量 30 万 $\mathrm{t}$, 品位 $0.7 \%$. 在我国其规 模仅次于个旧、大厂、都龙锡矿 (大兴安岭黄岗 46 万 $\mathrm{t}$ 锡和柿竹园 40 万 $\mathrm{t}$ 锡除外，两者均为难选冶和当前不可 


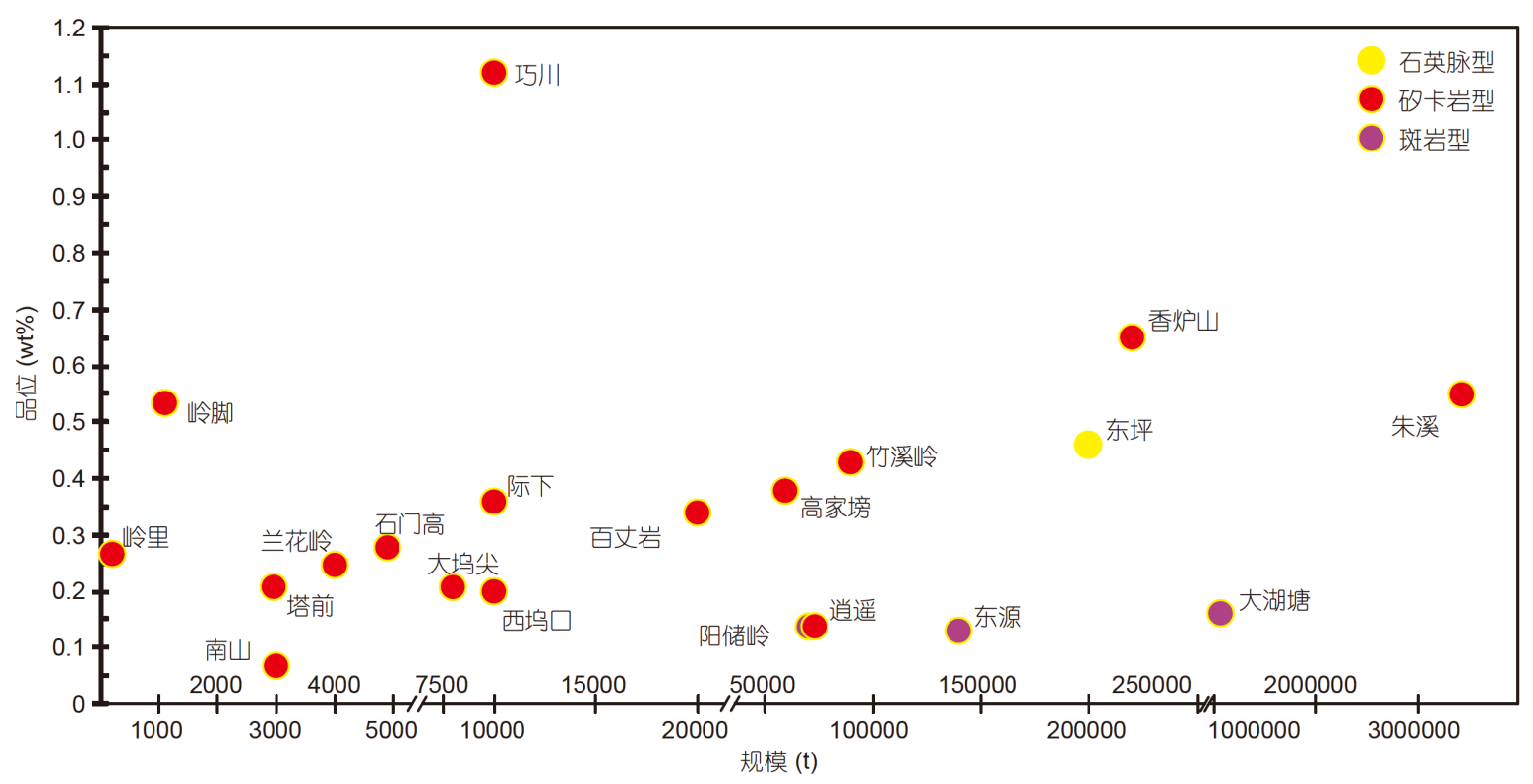

图 2 江南铇矿带矿石吨位与品位图

Figure 2 Resources v.s. grades of the W deposits in the Jiangnan W ore belt

利用资源). 迄今, 已经在江南铇矿带探明 $\mathrm{WO}_{3}$ 资源量 606 万t $($ 表 $S 1)$, 就资源量而言, 成为全球最大的铇矿带, 而且具有进一步找矿潜力.

类似于长江中下游斑岩-矽卡岩型铜多金属成矿 带, 江南铇矿带也表现为两期成矿. 主成矿期(150 135 $\mathrm{Ma}$ )的铇矿横贯全区, 仅赣西北地区的香炉山铇矿和曾 家垄锡矿的成矿时代为130 125 Ma(图S1, 表S1). 近些 年, 在长江中下游发现了越来越多的铇矿床, 例如东顾 $山^{[31]}$; 铇铜矿, 例如阮家湾和通江岭. 空间上从花岗质 岩体的接触带向上或向外具有铜铇到铜的分带 性 $^{[32-34]}$, 甚至在原来的铜矿体下部新发现铜铇矿体, 例 如江西武山.

形成斑岩与矽卡岩型矿床的关键取决于围岩成分, 当前寒武纪浅变质岩或者早期花岗质岩石为围岩, 通 常形成斑岩铇矿. 例如, 阳储岭铇矿的围岩为新元古代 双桥山群千枚岩、变凝灰质板岩和泥质板岩; 东源铇 矿的围岩是一套中新元古代变质岩屑砂岩、千枚状砂 岩、砂质板岩、千枚状板岩; 大湖塘斑岩铇矿区的成 矿围岩为新元古代花岗闪长岩体. 三者的共同特点是 在岩体的内外接触带形成细脉浸染状白铇矿矿化. 大 湖塘矿区的主矿体出现在围岩中 ${ }^{[2,35-38]}$, 而东源和阳储 岭的主矿体在成矿主岩花岗闪长岩体和二长花岗斑岩 体中 ${ }^{[5,39]}$. Wu等人 ${ }^{[40]}$ 通过对东源斑岩铇矿的钻孔岩心 编录, 识别出在花岗闪长岩体隆起部位发育有多个近
水平平行的矿体, 单一矿体一般长几十米至几百米, 厚 度为几米至几十米, 同一矿体内不同脉体在垂向上出 现脉体形态和矿物组合相似的变化规律. 寒武纪至三 叠纪沉积岩盖层中有多层位的碳酸盐岩, 不仅广泛分 布于江南古陆周围，而且呈NEE向复式福铍在古陆内 部局部出现. 当这些碳酸盐岩作为围岩, 通常形成矽卡 岩型铇矿以及锡矿”. 例如, 在朱溪矿区不仅有新元古代 双桥山群浅变质岩, 还有盖层岩石: (1) 石炭系黄龙组 白云岩; (2) 石炭系船山组灰岩; (3) 二叠系栖霞组、茅 口组碳酸盐岩等 ${ }^{[41-43]}$. 与成矿有关的侵人岩为晚侏罗 世的黑云母二长花岗岩、细粒花岗岩以及花岗斑岩. 当花岗质岩浆侵位时, 与碳酸盐岩相互作用形成了厚 层块状以石榴石和符山石为主的外矽卡岩及规模较小 的内矽卡岩, 在矽卡岩中均发育细粒浸染状白铇矿. 主 要矿化作用出现于退化蚀变作用(闪石、绿泥石、石 英和茧石为主)阶段. 同时, 一些浸染状矿化体出现在蚀 变花岗岩体内 ${ }^{[42,43]}$.

在江南铇矿带中, 铇矿区矿化分带性明显, 例如在 朱溪铇矿区，上部为沿断裂分布的石英脉状铜矿矿体, 下部为厚层矽卡岩型铇矿体. 元素分带为 $\mathrm{Cu} \rightarrow \mathrm{Cu}$ 、 $\mathrm{W} \rightarrow \mathrm{W}$ 的规律性, 体现出从上而下成矿温度有升高的 趋势, 由中温 $\rightarrow$ 中高温 $\rightarrow$ 高温 ${ }^{[4]}$. 在香炉山铇矿区, 在 黑云母二长花岗岩的隆起部位出现含铇云英岩, 外接 触带出现钙质矽卡岩铇矿体 (主矿体), 远接触带的石 
英-硫化物-白铇矿脉 ${ }^{[45]}$. 在逍遥铇矿区也有明显的矿化 分带性, 围绕花岗闪长岩体矿化分带现象明显(安徽地 质矿产局332地质大队内部资料, 2011), 从接触带向外 发育有W-Mo、Cu、Pb-Zn-Ag矿化. W-Mo矿体主要分 布在花岗闪长岩体与新元古界蓝田组和寒武系荷塘组 灰岩接触带, 矿化类型主要为矽卡岩型和石英脉型, 矿 石矿物有白铇矿和辉锄矿. 铜矿体主要位于距花岗闪 长岩南部 $500 \mathrm{~m}$ 处, 矿化类型主要为矽卡岩型和石英脉 型, 矿石矿物主要包括黄铜矿和磁黄铁矿. Pb-Zn-Ag矿 体主要位于距花岗闪长岩南部 $1000 \mathrm{~m}$ 处, 矿化类型主 要为热液脉型. 矿石矿物主要包括闪锌矿、方铅矿、 自然铋、辉铋银铅矿, 脉石矿物为方解石和石英 ${ }^{[46]}$. 此 外, 围绕赣西北彭山核杂岩矿化有明显的分带性, 近接 触带为曾家垄和尖峰坡矽卡岩型锡矿, 外围为张家垄 铅锌矿. $\mathrm{Xu}$ 等人 ${ }^{[47]}$ 通过翔实的 $\mathrm{S}-\mathrm{Pb}$ 同位素示踪, 及结 合前人获得成矿流体包裹体资料的研究, 发现这两类 矿床是一套与 $129 \mathrm{Ma}$ 高分异花岗岩(黑云母二长花岗 岩)有关的岩浆热液矿床系统.

\section{3 与成矿有关花岗质岩石}

在江南铇矿带中与成矿有关的花岗岩有两种类型, 其一是花岗闪长岩和花岗闪长斑岩, 包括东源、竹溪 岭、邓家坞、三堡、上金山、马头和高家塝; 其二是 黑云母二长花岗岩和黑云母花岗岩, 包括大湖塘、朱 溪、香炉山、曾家垄、阳储岭、百丈岩. 大多数与成 矿有关的花岗岩类显示出富含铀和针的高热花岗岩的 特点, 在岩体侵位和冷凝过程中往往形成几十米到上 百米厚的热变质带, 例如, 阳储岭、东源、朱溪等. 黑 云母二长花岗岩通常为似斑状或者等粒结构, 而花岗 闪长岩不仅有等粒结构和似斑状结构, 还有斑状结构. 在花岗闪长斑岩体中通常有大量包体, 这些包体除了 双桥山群千枚岩和板岩等围岩外, 还有闪长岩包体. 此 外, 在花岗质岩浆侵位之后可见闪长岩墙或辉绿岩墙 的侵位. Song等人研究发现两种不同类型花岗质岩石 形成的氧逸度不同，前者偏氧化环境，后者偏还原环 境, 与前者有关的铇矿规模相对较小, 与后者有关的铇 矿可以形成世界级大矿(作者待刊资料). 该特点与马来 西亚锡矿带极其类似, 以半岛中部走向近NS的Bentong-Raub缝合带为界, 西马来西亚发育一系列与 $\mathrm{S}$ 型 花岗岩有关的大型锡矿, 而东马来西亚则出现多个与 $\mathrm{I}$ 型花岗质岩石有关的小型锡矿，两个不同类型锡矿成 矿时代均为晚三叠世 ${ }^{[48,49]}$.
前人对江南铇矿带中有关花岗质岩石的岩石化学 进行了大量的研究, 通过对前人测试数据整理可以发 现花岗闪长岩类属于偏铝质花岗岩, 而黑云母二长花 岗岩属于过铝质花岗岩类(图S2(a)), 两者均属于高钾 钙碱性花岗岩, 但黑云母花岗岩的 $\mathrm{SO}_{2}$ 和 $\mathrm{K}_{2} \mathrm{O}$ 含量明显 高于花岗闪长岩, 而与彭山地区锡矿有关的花岗岩与 铇矿有关的黑云母二长花岗岩类似(图 $\mathrm{S} 2(\mathrm{~b})$ ). 在 $\mathrm{Zr}$ 与 $10000 \mathrm{Ga} / \mathrm{Al}$ 的二元图解(图S3(a))中反映出江南铇矿带 中所有与铇锡矿有关的花岗质岩石经历过强结晶分异 作用, 与铇矿有关的黑云母二长花岗岩属于高分异 $\mathrm{S}$ 型 花岗岩，与铇钼矿有关的花岗闪长岩属于高分异 $\mathrm{I}$ 型花 岗岩(图S3(b)). 与彭山锡矿和百丈岩铇矿有关的黑云 母二长花岗岩可能由于结晶分异程度很高, 导致这些 花岗岩的投点偏离了 $\mathrm{S}$ 型花岗岩的演化曲线. 在稀土元 素球粒陨石标准化图解和微量元素原始地幔标准化蜘 蛛网图(图S4)中可以看出, 与铇锡矿有关的黑云母二长 花岗岩和黑云母花岗岩表现出Eu、Ba、Sr、Ti强烈亏 损, 表明岩浆经历过强烈的结晶分异作用, 属于典型的 含铇锡花岗岩. 而江南铇矿带内铇矿有关的花岗闪长

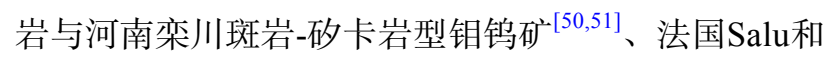
Castabone矽卡岩型铇矿有关的花岗质岩石类似 ${ }^{[52]}, \mathrm{La} /$ $\mathrm{Yb}$ 比值高, $\mathrm{Eu}$ 亏损不明显, 但具有 $\mathrm{Nb} 、 \mathrm{Ta} 、 \mathrm{P}$ 和 $\mathrm{Ti}$ 亏损, 表明来源于深部或者有较多地幔物质进人岩浆系统.

\section{4 问题讨论与矿床模型}

\section{1 斑岩铇矿一一种值得关注的矿床类型}

相对于斑岩铜矿和斑岩钼矿, 在全球范围对于斑 岩铇矿研究甚少, 而且程度很低, 关键在于长期以来斑 岩铇矿并不是一种重要工业性矿床类型. 在 20 世纪 70 90年代, 时值全球研究斑岩铜矿和斑岩钼矿的热 潮, 一些学者关注和探索了是否存在斑岩铇矿, 并初步 提出其基本特点. 在2010年之前, 已确定的比较典型斑 岩铇矿有加拿大New Brunswick的Mount Pleasant W (Mo)矿床 ${ }^{[53 \sim 55]}$ 、育空地区中南部的Logtung 矿床 ${ }^{[53]}$ 、 我国广东省莲花山和江西省阳储岭 ${ }^{[56 ~ 58]}$ 、韩国的Weolag 和Dae Hwain矿床 ${ }^{[59,60]}$. 然而, 这些矿床的规模都较 小, 经济价值不重要 ${ }^{[5]}$. 与斑岩铇矿有关的岩体规模一 般 $<10 \mathrm{~km}^{2}$, 属浅成-超浅成岩株、岩枝和岩墙. 其岩性 通常是花岗斑岩、石英斑岩、石英-长石斑岩等较酸 性岩石, 在剥蚀程度比较浅的地区, 往往与同源火山岩 共生 ${ }^{[61]}$. 谭运金 ${ }^{[57,58,62]}$ 提出斑岩铇矿具有一套特征的蚀 
变组合, 它们是钾化(包括钾长石化和黑云母化)、绿泥 石化、硅化、高岭石化、赤铁矿化及茧石化、碳酸盐 化. 各种蚀变在空间分布方面没有明显的垂直分带与 水平分带现象, 而是相互重叠. 值得指出的是, 不同于 斑岩铜矿和斑岩锄矿, 斑岩铇矿的围岩蚀变以强云英 岩化, 弱钾化和弱青盘岩化为特征. 因此, Davis和William-Jones ${ }^{[63]}$ 将其命名为斑岩一云英岩型铇矿. 除了对斑 岩铇矿地质特征研究以外, 还开展了部分矿床的流体 包裹体成矿温度和盐度测定, 总体认为是以中高温中 高盐度为特征 ${ }^{[55,63]}$. 但谭运金 ${ }^{[58]}$ 发现莲花山斑岩铇矿 成矿温度从高温延续到低温 $\left(650 \sim 150^{\circ} \mathrm{C}\right)$, 盐度也有较 大分布范围.

江南铇矿带中大湖塘超大型斑岩铇矿和阳储岭、 东源大型斑岩铇矿控制资源量达 130 万 $\mathrm{t}$, 彻底改变了铇 矿类型的格局, 斑岩型与矽卡岩型和石英脉型成为全 球3种最主要的铇矿床类型. 迄今, 我国对于斑岩铇矿 是否属于斑岩型矿床类型仍然有些疑虑，由于斑岩铇 矿与斑岩铜矿有一定的差异性. 其一, 斑岩铇矿与斑岩 锡矿类似, 含有大量以氟为特点的挥发组分, 因此含氟 矿物广泛发育, 例如, 云母类、黄玉和茧石, 无论在矿 石中还是与成矿有关的蚀变岩中均如此. 其二, 与成矿 有关的斑岩不是典型的斑状结构, 而通常是似斑状结 构. 迄今所知, 相对于斑岩铜矿, 全球所探明的斑岩铇 矿有关的岩体侵位相对较深，岩石通常表现为似斑状 构造. 其实, 在我国与绝大多数斑岩铜矿和斑岩锄矿有 关的花岗岩也呈现出似斑状结构, 仅仅在斑岩与同源 火山岩共存地区才可能见到具有典型斑状结构的花岗 岩类. 在国际上, 判别是不是斑岩型矿床, 最主要特点 是细脉浸染状构造. 网脉状裂隙是矿化富集的容矿空 间, 也是通过这些裂隙流体与围岩相互作用, 形成大面 积、大吨位、低品位的矿石. 在成矿岩浆高侵位后, 岩 体的结晶分异作用导致气体和液体在岩浆房的隆起部 位集中, 产生相当大的静水压力. 静水压力导致已经结 晶的花岗质岩石及上覆围岩的破裂，构成垂直上下最 大压力面的一组大致共轭的网状裂隙. 这些网状裂隙 的位置取决于静水压力与岩浆房上部岩石产生的静岩 压力相抵消构成的不受力面, 网状裂隙位于不受力面 的下部. 在江南铇矿带的大湖塘矿区, 白严纪黑云母二 长花岗质岩浆侵位相对较浅, $95 \%$ 以上的矿体发育于围 岩中, 而阳储岭和东源岩浆侵位相对较深, 矿体均发育 于岩体内部．Rusk等人 ${ }^{[64]}$ 对斑岩型矿床的容矿裂隙形 成过程及流体演化与成矿进行了深人的研究, 探讨了
成矿裂隙系统和矿化过程. 赵茂春等人 ${ }^{[65]}$ 进一步总结 将斑岩型矿床容矿裂隙系统的成因归纳为岩浆结晶冷 缩、侵位挤压、水岩分离和区域应力叠加4种类型，探 讨了裂隙分布与矿化规律性. 这些对于斑岩铜矿的研 究成果有助于理解玟岩铇矿的形成方式和过程.

\section{2 铇矿床中钻长石岩脉和钠长石岩脉的启示}

Song等人 ${ }^{[42]}$ 在朱溪矿区内识别出两类较为罕见的 含白铇矿岩脉, 分别为由富 $\mathrm{Ca}$ 斜长石(斜长石牌号 $(\mathrm{An})$ 平均值 $=91,90 \mathrm{vol} \%)+$ 白铇矿 $(3 \mathrm{vol} \%)+$ 磷灰石 $(2.5 \mathrm{vol} \%)$ +铁铁矿 $(1.5 \mathrm{vol} \%)+$ 榍石 $(1 \mathrm{vol} \%)$, 以及少量 $(2 \mathrm{vol} \%)$ 萤 石、葡萄石、黄铜矿、磁黄铁矿、黄铁矿、闪锌矿、 金红石和晶质铀矿组成的钙长岩脉, 由富 $\mathrm{Na}$ 斜长石( 斜 长石牌号(An)值 $<2,90 \mathrm{vol} \%$ )、石英 $(5 \mathrm{vol} \%)$ 、白云母 ( $2 \mathrm{vol} \%$ ) 和白铇矿 ( $2 \mathrm{vol} \%$ )组成的钠长岩脉(作者待刊 资料).

含白铇矿并以钙长石 $(A n>90)$ 为主的钙长岩十分 罕见, 除朱溪矿床外, 目前仅在伊比利亚半岛规模最大 的矽卡岩铇矿床 (Los Santos)中被报道过 ${ }^{[66]}$. 为何含白 铇矿钙长岩目前仅在超大型的矽卡岩型白铇矿矿床中 被识别出? 是怎样的机制控制着含白铇矿钻长岩的形 成? Song等人 ${ }^{[42]}$ 研究发现, 钻长岩是由富集Si、Al、 W、Ti、P、U、 $\mathrm{H}_{2} \mathrm{O}$ 和F的残余岩浆(流体)遭受纯灰岩 (不含 $\mathrm{Mg}$ ) 的混染作用而形成.

在朱溪矿床中大量出现不同规模(厚度为 $1 \mathrm{~cm} \sim$ $5.1 \mathrm{~m}$ )的含白铇矿钠长岩脉, 明显不同于W-Sn-Nb-Ta等 稀有金属矿床中常见的钠长石花岗岩，主要体现于以 下几个方面: (1) 产出形态上, 钠长石花岗岩通常形成 于花岗质侵人体顶部，并与其他花岗质岩石呈渐变过 渡状态. 例如, 广西栗木Sn-Nb-Ta矿的水溪庙岩体 ${ }^{[67]}$ 、 法国中央高地与 $\mathrm{Sn}-\mathrm{Nb}-\mathrm{Ta}-\mathrm{W}$ 矿化相关的Beauvoir岩 体 ${ }^{[68]}$; 而朱溪含白铇矿钠长岩呈独立脉体产出. (2) 矿 物组成上, 钠长石花岗岩主要由石英 $(20 \mathrm{vol} \% \sim 40$ vol $\%)$ 、钠长石 $(25 \mathrm{vol} \% \sim 55 \mathrm{vol} \%)$ 和钾长石 $(4 \mathrm{vol} \%$ $32 \mathrm{vol} \%$ )组成，而朱溪钠长岩完全缺失钾长石、石英含 量偏低 $(3 \mathrm{vol} \% \sim 5 \mathrm{vol} \%)$ 、并高度富集钠长石 $(90 \mathrm{vol} \%$ $92 \mathrm{vol} \%$ ). (3) 元素组成上, 朱溪钠长岩相对于常见的钠 长石花岗岩具有低 $\mathrm{Si}_{2} \mathrm{O}$ (分别为 $60 \mathrm{wt} \%$ 与 $70 \mathrm{wt} \%$ )、低 $\mathrm{K}_{2} \mathrm{O}$ (分别为 $1.8 \mathrm{wt} \%$ 与 $3.2 \mathrm{wt} \% \sim 4.5 \mathrm{wt} \%$ )、高 $\mathrm{Na}_{2} \mathrm{O}$ (分别 为 $\sim 7 \mathrm{wt} \%$ 与 $3 \mathrm{wt} \% \sim 4 \mathrm{wt} \%)$ 的特征. Song等人通过系统的 显微镜下观察、主微量元素分析、 $\mathrm{Sr}-\mathrm{Nd}$ 同位素分 析、矿物学分析研究, 论证了朱溪含白铇矿钠长岩是 
由高度结晶分异的残余岩浆形成的富 $\mathrm{Na}$ 、高盐度富水 熔体结晶形成(作者待刊资料). 值得注意的是, 前人实 验研究表明，在细晶花岗岩体系(Qz-Ab-Or)随水压 $\left(P_{\mathrm{H}_{2} \mathrm{O}}\right)$ 或熔体中 $\mathrm{F}$ 含量的升高, 最低共熔点逐渐朝钠长 石 $(\mathrm{Ab})$ 端元偏离, 且随压力的升高, 石英含量逐渐降低 而碱性长石含量逐渐升高, 而在压力不变时, 随 $\mathrm{H}_{2} \mathrm{O}$ 活 度 $\left(a_{\mathrm{H}_{2} \mathrm{O}}\right)$ 增大, 最低共熔点中钠长石组分逐渐升高而钾 长石组分逐渐降低 ${ }^{[69]}$; 更为重要的是, 只有当压力 $>3 \mathrm{kbar}$ 时, 石英才能与钠长石和钾长石平衡, 而压力 $<3 \mathrm{kbar}$ 时, 石英将与碱性长石 (钠长石-钾长石固溶体) 共存 ${ }^{[70,71]}$. 此外, Panjasawatwong 等人 ${ }^{[72]}$ 开展的斜长石熔体平衡实验研究也表明随着压力增大，越容易结晶 富 $\mathrm{Na}$ 斜长石．基于上述论述，可以得知只有花岗质岩 浆在压力 $>3 \mathrm{kbar}$ 的条件发生高度结晶分异, 当残余岩 浆达到水饱和状态 $\left(a_{\mathrm{H}_{2} \mathrm{O}}=1\right)$ 时，才有利于钠长石发生大 规模的结晶. 值得注意的是, 朱溪矿床中的含白铇矿钠 长岩分布于细粒花岗岩的下部，而细粒花岗岩是朱溪 矿区除含白铇矿钠长岩、钲长岩外, 演化程度最高的 长英质岩脉. 由此说明形成含白铇矿钠长岩的残余岩 浆来源于深部岩浆房, 而不是结晶细粒花岗岩的分异 熔体进一步演化而成(作者待刊资料). 为此, 朱溪矿区 深部应该在 $10 \mathrm{~km}(>3 \mathrm{kbar})$ 左右深度存在一个岩浆房, 该岩浆房结晶演化后形成的水饱和熔体发生迁移后结 晶形成了含白铇矿钠长岩. 这与矽卡岩铇矿床通常形 成于深成环境 $(5 \sim 15 \mathrm{~km})$ 的特征吻合 ${ }^{[73]}$. 因为矽卡岩铇 矿通常与具有等粒状、粗粒结构且未遭受明显蚀变的 深成岩基相关，这些岩基周围发育高温的变质带并伴 随着伟晶岩和细晶岩脉的形成 ${ }^{[74]}$.

朱溪含白铇矿钙长岩和含白铇矿钠长岩的出现, 具有两点重要指示: (1) 朱溪矿床的成矿相关岩体为浅 部地壳物质部分熔融形成的岩浆发生结晶分异后而形 成; (2) 朱溪矿床成矿相关的初始岩浆相对于江南铇矿 带上的W-Mo矿床成矿相关的I型花岗质岩浆更加富 W, 并且侵位深度更深. 因为钛铁矿系列的 $\mathrm{S}$ 型花岗岩的侵 位深度通常大于磁铁矿系列花岗岩 ${ }^{[75]}$. 此外, 朱溪黑云 母二长花岗岩中出现的呈自形板状，并被斜长石包裹 的转熔相钾长石, 同样有力地支持朱溪矿床的成矿相 关岩浆起源于含白云母的变质沉积岩的部分熔融 ${ }^{[41,76]}$. 地壳物质重融有利于铇矿床形成 ${ }^{[77 ~ 79]}$, 并且变质沉积 岩中的W含量随其变质程度升高而显著降低 ${ }^{[80]}$. 为此, 富集的变质沉积岩是铇矿床理想岩浆源区 ${ }^{[81,82]}$, 并且 深度为 $20 \mathrm{~km}$ 左右的中地壳最容易发生部分熔融, 形成
相对富 $\mathrm{W}$ 的初始岩浆. 因为根据常见的地温梯度 $\left(20^{\circ} \mathrm{C} /\right.$ $\mathrm{km}$ )计算 ${ }^{[83]}$, 在 $20 \mathrm{~km}$ 的地壳深度, 地壳岩石的温度约为 $400^{\circ} \mathrm{C}$, 而当岩石温度达到 $400^{\circ} \mathrm{C}$ 时将由脆性向塑性转 变 ${ }^{[84]}$. 为此, 在地壳 $20 \mathrm{~km}$ 的深度, 很可能存在一个由 脆性向塑性转变的过渡带. 地震剖面显示在江南铇矿 带相邻的长江中下游成矿带的铜陵矿集区附近的 $22 \mathrm{~km}$ 左右深部地壳中存在一个近于水平, 并且可能代 表了中、下地壳边界的折射结构，边界之下为塑性岩 层 $^{[85]}$; 而实验研究表明这种区域性的刚性-塑性岩性界 面有利于深部上侵的岩浆沿脆-韧性界面横向侵位形 成岩床 ${ }^{[86]}$. 这与前人对华南地区的地球物理研究结果 吻合, 例如, Zhang等人 ${ }^{[87]}$ 研究提出在华南地区中地壳 的底部 $(\sim 20 \mathrm{~km})$ 存在一层 $4 \sim 5 \mathrm{~km}$ 厚的铁镁质岩石. 这些 铁镁质岩浆的侵位很可能是对晚侏罗世至早白严世俯 冲的古太平洋板块发生撕裂所引发的岩石圈伸展、软 流圈上涌的积极响应 ${ }^{[81]}$. 江南古陆铇矿带上的新元古 代双桥山群高度富集铇元素 $(11.82 \mu \mathrm{g} / \mathrm{g})^{[88]}$ ，显著高于 上地壳中铇的平均含量 $(1.9 \mu \mathrm{g} / \mathrm{g})^{[89]}$. 在基性岩浆的底 侵作用下，这些富铇的双桥山群发生部分熔融形成的 岩浆深度侵位，发生高度结晶分异后形成了含白铇矿 的钙长岩和钠长岩, 并伴随大规模的铇矿化作用.

\section{3 钨矿床模型与成矿动力学模型}

关于铇锡矿床(包括斑岩铇矿)形成的地质背景, 在 苏联的教科书中将与花岗岩有关的铇锡矿都归为地槽 禇皱回返期间的产物. Mitchell和Garson ${ }^{[90]}$ 与Sawkins ${ }^{[91]}$ 率先运用板块构造理论提出铇锡矿形成于碰撞造山带,

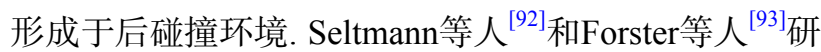
究提出中欧厄尔士地区铇锡矿床碰撞成矿的动力学模 型, Romer和Kroner ${ }^{[82]}$ 认为横贯捷克与德国交界处的厄 尔士、法国中央高原、法国与西班牙之间的比利牛斯 山、西班牙-葡萄牙半岛到英国康沃尔巨型铇锡成矿 带是在Pangea超大陆聚合晚期出现的大规模成矿. 铇 锡矿另一个重要的成矿背景就是活动大陆边缘弧后伸 展带. 例如, 在南美安第斯大陆边缘(智利-秘鲁-阿根廷) 新生代斑岩铜矿带与弧后玻利维亚锡(铇)矿带 ${ }^{[94 ~ 96] 、 ~}$ 在缅甸东部密支那新特提斯洋缝合带以Monywa代表 的NS走向斑岩铜矿带与东侧弧后伸展带中出现的平行 分布的锡(铇)矿带 ${ }^{[24]}$.

Mao等人研究提出东南沿海发育的中晚侏罗世斑 岩-矽卡岩铜多金属成矿带与弧后地区的南岭花岗岩 有关的铇锡成矿带空间上平行分布，与上述的南美安 
第斯和缅甸东部两个平行成矿带相同(作者待刊资料). 但是，江南铇矿带与长江中下游斑岩-矽卡岩铜多金属 矿带平行分布，走向近EW或者NEE向，与前一组铜矿 与铇锡平行成矿带几乎垂直. 显而易见, 位于江南古陆 及东延地区的铇矿带并非形成于活动大陆边缘弧后伸 展带, 更不是碰撞造山带, 可能显示出一个新成矿背景. 我国东部晚中生代大规模岩浆活动与Izanagi或者古太 平洋板块俯冲和后俯冲关系密切. 在东部大陆最早出 现弧岩浆活动大约在 $175 \mathrm{Ma}^{[11,12]}$, 也基本代表了板块 俯冲的开始. 之后无论是俯冲板块后撤还是运动方向 发生转向, 平行大陆呈NNE向运动, 导致岩石圈发生伸 展. 该伸展事件不仅导致华北克拉通被破坏 ${ }^{[97]}$ ，而且整 个东亚东部边缘遭受强烈破坏和改造, 并以大规模伸 展为标志. 长江中下游地区由挤压转变为伸展的重要 标志是发育了宁芜、庐枞和繁昌等一系列NNE走向的 盆地. 其底部最老的钙碱性火山岩的成岩时代为 135 $\mathrm{Ma}^{[98]}$, 这一转折时间与华北和东北, 乃至蒙古-鄂霍次 克造山带以南伸展盆地底部火山岩所显示的时间基本 一致. 而长 $1200 \mathrm{~km}$ 和宽 $500 \mathrm{~km}$ 的东南沿海火山岩带 (包括武夷山北坡或者江南古陆南侧)的主要岩性为英 安质-流纹质火山岩, 喷发时代为143 110 $\mathrm{Ma}^{[99 \sim 101]}$, 说 明从俯冲到后俯冲转变的时代也是从华南地区伊始. $\mathrm{Mao}$ 等人 ${ }^{[102]}$ 发现钦杭、长江中下游和太行东北-大兴 安岭东南 3 个斑岩-矽卡岩型铜矿带走向NE，平行分布， 均位于两个构造单元的结合带或者沿深大断裂发育. 推测俯冲板片沿这些部位撕裂，导致软流圈上升并引 发地壳物质重熔，形成了壳源花岗质岩石及江南铇矿 带, 而俯冲板片重熔则形成长江中下游铜矿带, 初步提 出其成矿动力学模型(图3(a) $)^{[37,38]}$. 而在140 80 Ma期 间, 整个东亚东部发生岩石圈伸展, 原俯冲板片碎裂下

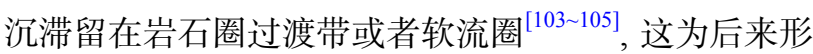
成类似于弧岩浆和斑岩铜矿提供物质来源. 正是在这 种大背景下，沿长江中下游发育NNE向的走滑拉分盆 地及玢岩铁矿，在南侧的江南古陆出现了像彭山核杂 岩，130 125 Ma曾家垄锡多金属成矿系统和香炉山铇 矿在其内部或者周围形成，显示出与地壳重熔型花岗 岩的密切成因关系(图3(b)). 正是由于软流圈上涌和热 侵蚀, 导致地壳重熔形成与 $\mathrm{Sn}$ 有关的花岗岩, 并有一定 幔源物质加人, 因此显示出 $\mathrm{A}$ 型花岗岩的特点 ${ }^{[47]}$.

矿床模型是找矿勘查的理论基础. 江南铇矿带以 斑岩-矽卡岩铇矿为特征，按照成矿有关的岩体可以分 为与高氧逸度花岗闪长岩有关的铇矿成矿系统和与低
氧逸度黑云母二长花岗岩有关的铇矿成矿系统. 这两 种类型矿床在整个矿带交织出现, 但总体来讲, 前一个 系统的矿床数量在东部增多. 铇和锡均为相对亲地壳 元素，在地质历史演化期间，两者往往趋向在地壳富 集 ${ }^{[106]}$. 在同样地质构造背景下，为什么会形成两种类 型花岗质岩石及其相关的成矿系统？花岗闪长岩类明 显有地幔物质的加人，目前来看加人的形式有两种方 式: 其一, 新元古代双桥山群不仅有以千枚岩和板岩为 代表的富铝质沉积岩，而且在局部有中基性-基性火山 岩夹层, 甚至在东部存在元古代的蛇绿岩带. 因此, 经 历同样受软流圈上涌而驱动的地壳重熔，形成了不同 的岩浆类型，包括S型和I型花岗质岩石 ${ }^{[5]}$ ，甚至由于中 基性-基性火山岩的存在，在岩浆-热液活动过程中，其 中富含的铜元素被淋滤出并携带进人成矿系统 ${ }^{[37,107]}$, 形成像大湖塘、朱溪和三堡这样的含铜铇矿床. 其二, 也可能由于当地壳发生重熔时有幔源岩浆的注人导致 形成氧化性的花岗闪长岩类，并降低了成铇矿的能力 (作者待刊资料).

无论是基性岩抑或在地壳重熔时直接进人岩浆, 抑或在岩浆形成晚期注人岩浆房，岩浆性质仍然是以 地壳物质为主，花岗闪长岩浆和黑云母二长岩浆都富 含水和挥发组分氟, 岩浆经历强烈的结晶分异作用, 结 果导致硅质、碱质、挥发组分及携带的成矿元素在岩 浆房的隆起部位富集. 值得指出的是, 在江南铇矿带中 含矿岩浆侵位深度较大, 所有的矿体, 无论是斑岩型还 是矽卡岩型均位于岩体的近接触带. 前面已经述及, 矿 化赋存的细网状裂隙系统位于静岩压力/静水压力比值 等于零面之下，当斑岩矿体出现在岩体内外接触带附 近，说明成矿深度较大，当斑岩矿体在岩体垂直上方， 距离岩体越远表明成矿深度较小。当围岩是前震旦纪 浅变质岩或者早期的花岗质岩石，则形成斑岩成矿系 统(图4); 当围岩是碳酸盐岩或者碳酸盐岩夹层，则形 成矽卡岩型铇矿。在朱溪矿区有大厚层碳酸盐岩为围 岩, 形成厚度达上百米的矽卡岩型铇矿体 ${ }^{[43]}$; 而当震旦 纪、寒武纪和奥陶纪碳酸盐岩与砂页岩互层为围岩, 则形成似层状铇矿体或锡矿体，例如，逍遥、香炉山、

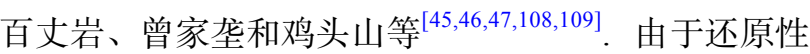
强的 $\mathrm{S}$ 型黑云母二长花岗岩通常形成超大型铇矿，因此 无论是矽卡岩型还是斑岩型，在其上部都有十分强的 围岩蚀变发育(图4). 但与强氧化性I型花岗闪长岩有关 的铇矿规模相对较小，围岩蚀变与矿体在空间上紧密 相连. 如果在成矿岩体的内外接触带发育有与区域构 


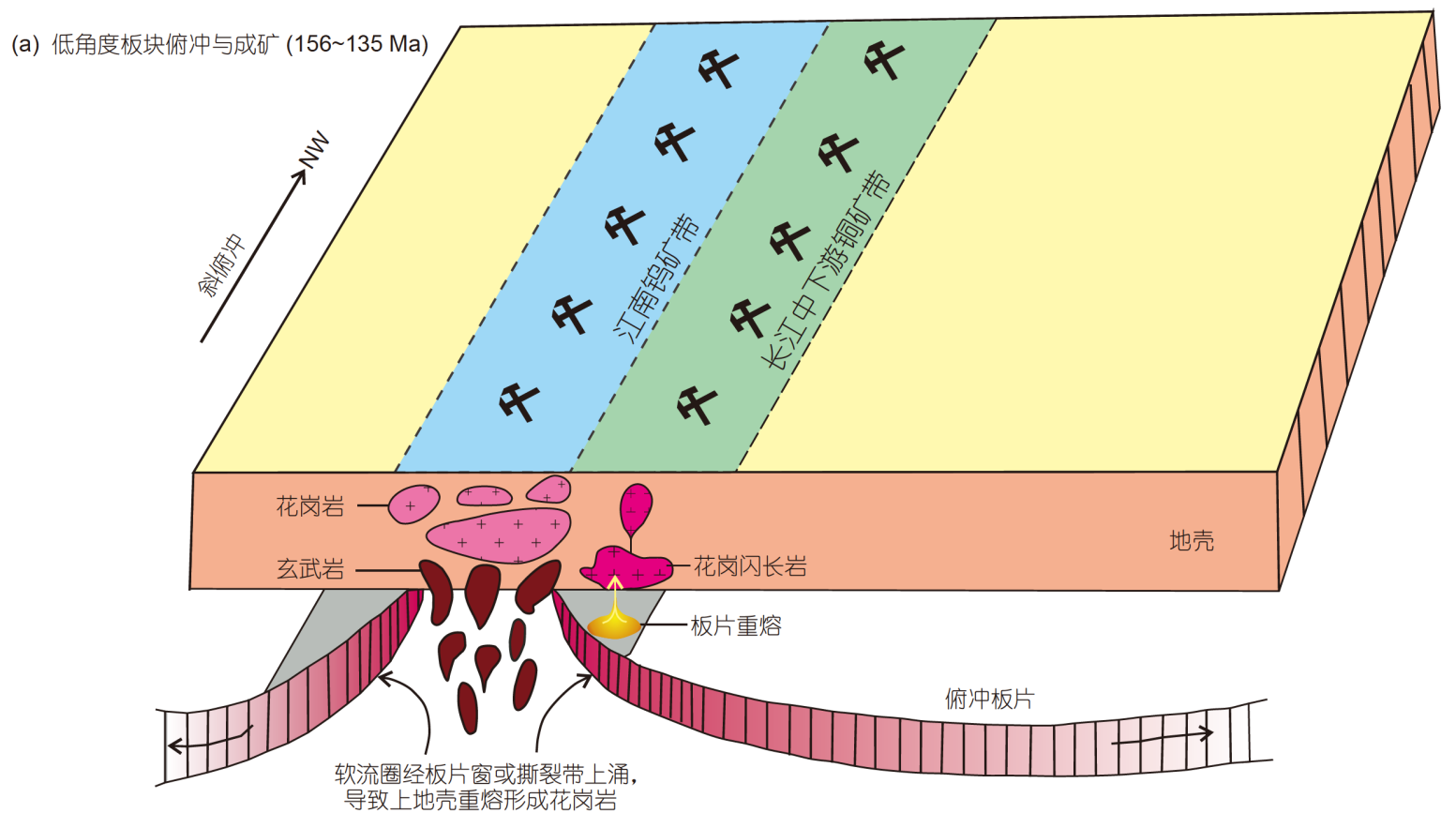

(b) 后俯冲伸展与成矿 $(135 \sim 125 \mathrm{Ma})$

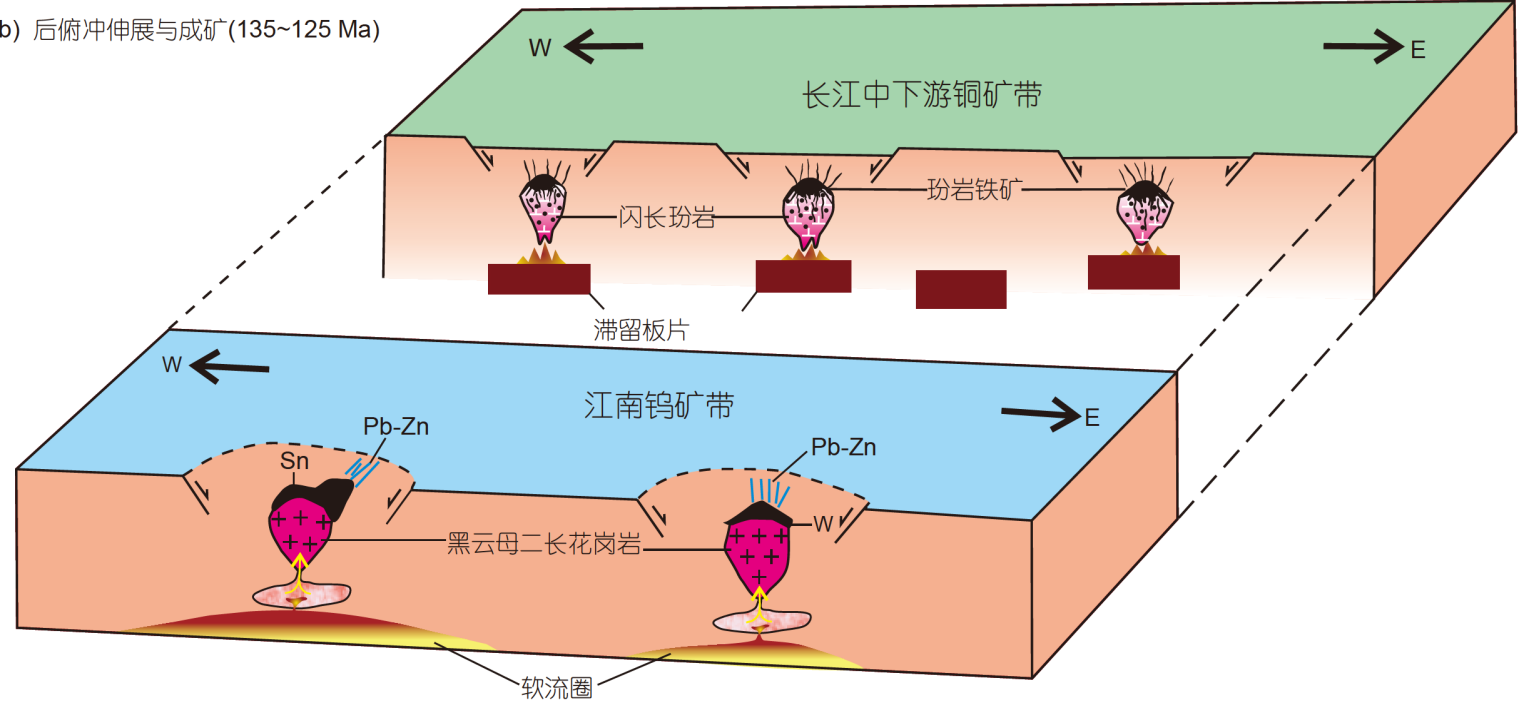

图 3 江南铇矿带与长江中下游铜多金属矿带成矿动力学模型. (a) Izanagi或者古太平洋板块俯冲沿华南地块与华北克拉通及秦岭造山带的构 造结合部位发生撕裂(156 135 Ma), 板片重熔并经过在地壳的同化混染过程, 沿长江中下游形成了高钾钙碱性花岗岩和有关的斑岩-矽卡岩铜 多金属矿带, 而软流圈上涌和热侵蚀导致上地壳重熔, 形成过铝质-偏铝质花岗岩及江南斑岩-矽卡岩铇矿带; (b) $135 \mathrm{Ma}$ 后俯冲板片抑或后撤 抑或转向, 发生NNE向走滑, 形成了一系列走滑拉分盆地(例如宁芜和庐枞盆地)和变质核杂岩(例如赣西北彭山穹窿), 其内发育有滞留板片重熔 形成的玢岩铁矿和地壳重熔形成的高分异花岗岩有关的铇锡矿, 时代为 $135 \sim 125 \mathrm{Ma}$

Figure 3 Tectonic model of the geodynamic setting for both $\mathrm{Cu}-\mathrm{Au}-\mathrm{Mo}-\mathrm{Fe}$ porphyry and skarn deposits along the Middle to Lower Yangtze River belt (MLYRB) and W and W-Mo porphyry and skarn deposits in the Jiangnan tungsten belt (JNB). (a) The subducting Paleo-Pacific (Izanagi) plate tear-off along the tectonic boundary between the South China block and the North China Craton-Qinling-Dabie orogenic belt (156-135 Ma), the magma, which formed by partial melting of the subducted plate, contaminated by the crustal material, forming the high potassium Ca-alkaline series granitic rocks and the associated $\mathrm{Cu}-\mathrm{Au}-\mathrm{Mo}-\mathrm{Fe}$ porphyry and skarn deposits along the MLYRB. Meanwhile, the intrusion of a mantle-derived magma, whose formation induced by the upwelling of asthenosphere, caused the partial melting of supracrustal material and formed metaluminous-peraluminous granitic rocks and the associated W-Mo and W porphyry and skarn deposits in the JNB. (b) The rollback or rotation of the subducted plate occurred after 135 Ma, accompanying NNE-trending strike-slip and forming a series of terrigenous rift basins (e.g., the Ningwu and Luzong basin) and metamorphism core complex (e.g., the Pengshan metamorphic dome in northwest Jiangxi Province). The apatite-magnetite Fe deposits, which are associated with the granitic rocks that derived from partial melting of the stagnant slab, or the W-Sn deposits (135-125 Ma), which associated with the highly fractionated granitic rocks that derived from crust anataxis 

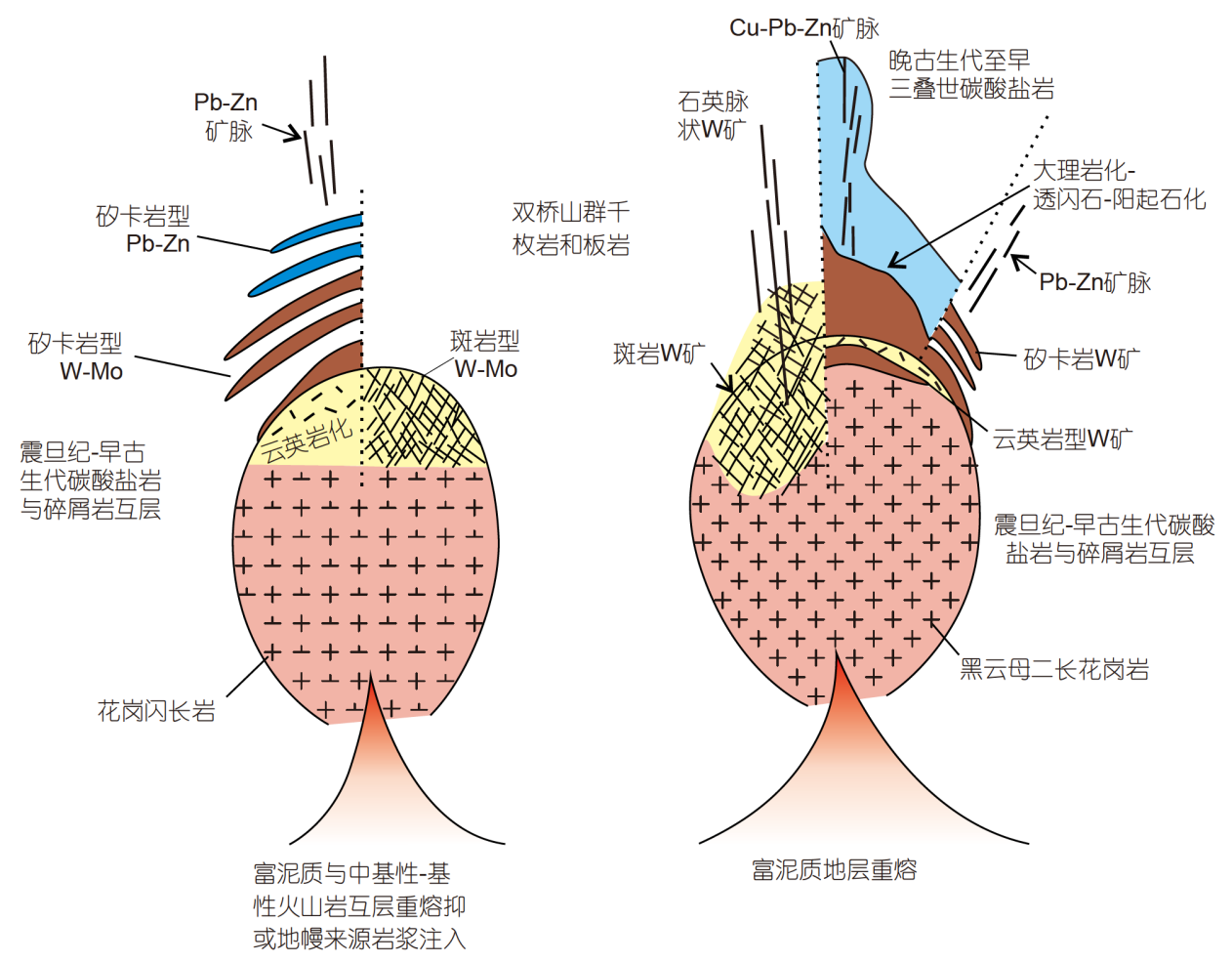

图 4 江南铇矿带斑岩-矽卡岩 $\mathrm{W} \pm \mathrm{Mo}$ 矿床及远接触带脉状Pb-Zn-Ag \pm Cu矿床成矿模式图

Figure 4 Deposit model for the relationship among the porphyry-skarn W and W-Mo, and distal vein $\mathrm{Pb}-\mathrm{Zn}-\mathrm{Ag} \pm \mathrm{Cu}$ in the Jiangnan W ore belt

造活动有关的次级断裂系统, 则会出现白铇矿和黑铇 矿共存的石英脉型铇矿.

此外, $\mathrm{Wu}$ 等人 ${ }^{[40]}$ 基于在东源铇矿区花岗闪长斑岩 隆起部位识别出多个平行水平分布的矿体, 结合前人 的研究成果, 初步研究提出一个多旋回W矿体和蚀变 体的矿化过程模型, 即: 岩浆侵位到地壳浅部, 岩浆降 温和浮力减少阻止进一步上升 ${ }^{[110]}$. 在早阶段, 岩浆释 放了一些酸性气体, 如 $\mathrm{HCl}$ 和 $\mathrm{H}_{2} \mathrm{~S}$, 导致似斑状花岗闪 长岩和周围的板岩和变质砂岩蚀变为绿泥石、绿帘石 和方解石组合 ${ }^{[111]}$. 随着降低温度, 岩浆顶部首先结晶, 下部岩浆释放酸性气体，这些酸性气体导致顶部已固 结的岩体中钾长石和黑云母蚀变为绢云母 ${ }^{[112]}$ (图S5 (a)). 熔体中的溶解水随着上部固化向下部熔体中迁移, 当下部熔体中水饱和后成核形成的气泡又向上运移聚 集. 聚集的气泡形成流体, 随着流体压力的增加, 在上 部固化的花岗闪长岩中产生裂隙, 造成第一旋回的脉 体形成(图S5(b)). 在释放这次流体之后, 下部岩浆中的 $\mathrm{H}_{2} \mathrm{O}$ 变得不饱和. 当等温的固化岩浆的界面逐渐向下 退, 上述过程会重复出现(图S5(c), (d)). 当整个花岗闪 长岩的结晶过程完成, 产生了东源矿床中出现多旋回
的W脉体.

\section{5 进一步找矿的思考}

“绿水青山就是金山银山”理念提出之后, 我国进 人了找矿勘查新时代, 充分考虑环保的要求, 务必与国 际接轨, “找大矿、找富矿和找浅矿”是新时代找矿的 主要目标. 作为内生金属矿床, 大型-超大型矿床即使 位于深部, 其浅表也必然有异常的显示. 例如, 朱溪世 界级铇矿的主矿体位于地下800 2000多米, 但在地表 有大面积的透门石-阳起石化; 大湖塘世界级斑岩铇矿 体上部和外围的强烈云英岩化和绢云母化, 在地表达 数十平方千米范围; 即使像阳储岭斑岩铇矿储量仅 7 万 $\mathrm{WO}_{3}$, 围岩蚀变也十分强烈, 有钾长石化、硅化、 绢云母(白云母)化、绿泥石化、碳酸盐化和黄铁绢英 岩化 ${ }^{[113]}$, 并具有一定的分带性, 即钾硅化 $\rightarrow$ 石英绢云 母化 $\rightarrow$ 绿泥石和碳酸盐化 ${ }^{[114]}$. 因此, 运用遥感开展找 矿, 机载高光谱+航重开展普查, 地面地质+水系重砂 +地球化学 + 红外光谱圈定靶区, 矿床模型+地面地球物 理+钻探+红外光谱地表下矿体控制, 将推动在江南铇 矿带和长江中下游成矿带以及相同地质背景下寻找铇 
矿和铇铜矿取得新突破.

在已知矿区，按照研究提出的矿床模型，花岗质岩

体近接触带的斑岩-矽卡岩型以及脉状铇矿与远接触
带的脉状Pb-Zn或者Cu-Pb-Zn矿互为找矿的指示，关注 在已知铇矿矿床外围寻找铅锌铜矿，在铅锌铜矿的下 部或者岩体接触带开展铇矿找矿勘查.

致谢＼cjkstart感谢江西地质矿产开发局和安徽地质勘查开发局及下属有关地质队同事们在野外地质调查期间给予的热诚支持和帮 助; 感谢江西地勘基金办公室的支持和合作; 感谢中国科学院地球化学研究所胡瑞忠研究员邀请撰稿.

\section{参考文献}

1 Xiang X K, Chen M S, Zhan G N, et al. Metallogenic geological conditions of Shimensi tungsten-polymetallic deposit in north Jiangxi Province (in Chinese). Contrib Geol Miner Resour Res, 2012, 27: 143-155 [项新葵, 陈茂松, 詹国年, 等. 赣北石门寺矿区铇多金属矿床成矿地质条件 初步研究. 地质找矿论丛, 2012, 27: 143-155]

2 Xiang X K, Wang P, Zhan G N, et al. Geological characteristics of Shimensi tungsten polymetallic deposit in northern Jiangxi Province (in Chinese). Miner Depos, 2013, 32: 1171-1187 [项新葵, 王朋, 詹国年, 等. 赣北石门寺超大型铇多金属矿床地质特征. 矿床地质, 2013, 32: 1171-1187]

3 Chen G H, Wan H Z, Shu L S, et al. An analysis on ore-controlling conditions and geological features of the Cu-W polymetallic ore deposit in the Zhuxi area of Jingdezhen, Jiangxi Province (in Chinese). Acta Petrol Sin, 2012, 28: 3901-3914 [陈国华, 万浩章, 舒良树, 等. 江西景德镇朱溪 铜铇多金属矿床地质特征与控矿条件分析. 岩石学报, 2012, 28: 3901-3914]

4 Wang X G, Liu Z Q, Liu S B, et al. LA-ICP-MS zircon U-Pb dating and petrologic geochemistry of fine grained granite from Zhuxi Cu-W deposit, Jiangxi Province and its geological significance (in Chinese). Rock Miner Anal, 2015, 34: 592-599 [王先广, 刘战庆, 刘善宝, 等. 江西朱溪铜铇 矿细粒花岗岩LA-ICP-MS锆石U-Pb定年和岩石地球化学研究. 岩矿测试, 2015, 34: 592-599]

5 Mao J W, Xiong B K, Liu J, et al. Molybdenite Re/Os dating, zircon U-Pb age and geochemistry of granitoids in the Yangchuling porphyry W-Mo deposit (Jiangnan tungsten ore belt), China: Implications for petrogenesis, mineralization and geodynamic setting. Lithos, 2017, 286-287: 35-52

6 Bai W J, Gan Q G, Yang J S, et al. Discovery of well-reserved ophiolite and its basical characters in Southeastern margin of the Jiangnan ancient continent (in Chinese). Acta Petrol Miner, 1986, 5: 289-299 [白文吉, 甘启高, 杨经绥, 等. 江南古陆东南缘蛇绿岩完整层序剖面的发现和基 本特征. 岩石矿物学杂志, 1986, 5: 289-299]

7 Gao L Z, Yang M G, Ding X Z, et al. SHRIMP U-Pb zircon dating of tuff in the Shuangqiaoshan and Heshangzhen groups in South ChinaConstraints on the evolution of the Jiangnan Neoproterozoic orogenic belt (in Chinese). Geol Bull China, 2008, 27: 1745-1752 [高林志, 杨明桂, 丁孝忠，等. 华南双桥山群和河上镇群凝灰岩中的锆石SHRIMP U-Pb年龄——对江南新元古代造山带演化的制约. 地质通报，2008，27: 1745-1752]

8 Ye M F, Li X H, Li W X, et al. SHRIMP zircon U-Pb geochronological and whole-rock geochemical evidence for an early Neoproterozoic Sibaoan magmatic arc along the southeastern margin of the Yangtze Block. Gondwana Res, 2007, 12: 144-156

9 Zhao J H, Zhou M F, Yan D P, et al. Reappraisal of the ages of Neoproterozoic strata in South China: No connection with the Grenvillian orogeny. Geology, 2011, 39: 299-302

10 Zhou G Q. The discovery and significance of the northeastern Jiangxi Province ophiolite (NEJXO), its metamorphic peridotite and associated high temperature-high pressure metamorphic rocks. J Southeast Asian Earth Sci, 1989, 3: 237-247

11 Liu X, Fan H R, Santosh M, et al. Remelting of Neoproterozoic relict volcanic arcs in the Middle Jurassic: Implication for the formation of the Dexing porphyry copper deposit, Southeastern China. Lithos, 2012, 150: 85-100

12 Wang Q, Zhao Z H, Jian P, et al. SHRIMP zircon geochronology and Nd-Sr isotopic geochemistry of the Dexing granodiorite porphyries (in Chinese). Acta Petrol Sin, 2004, 20: 315-324 [王强, 赵振华, 简平, 等. 德兴花岗闪长斑岩SHRIMP锆石U-Pb年代学和Nd-Sr同位素地球化学. 岩石学报, 2004, 20: 315-324]

13 Zhong Y F, Ma C Q, She Z B, et al. SHRIMP U-Pb zircon geochronology of the Jiuling granitic complex batholith in Jiangxi Province (in Chinese). Earth Sci-J China Univ Geosci, 2005, 30: 685-691 [钟玉芳, 马昌前, 余振兵, 等. 江西九岭花岗岩类复式岩基锆石SHRIMP U-Pb 年 代学. 地球科学一中国地质大学学报, 2005, 30: 685-691]

14 Wu R X, Zheng Y F, Wu Y B, et al. Reworking of juvenile crust: Element and isotope evidence from Neoproterozoic granodiorite in South China. Precambrian Res, 2006, 146: 179-212

15 Zhou T F, Fan Y, Yuan F. Advances on petrogenesis and metallogenic study of the mineralization belt of the Middle and Lower Reaches of the Yangtze River area (in Chinese). Acta Petrol Sin, 2008, 24: 1665-1678 [周涛发, 范裕, 袁峰. 长江中下游成矿带成岩成矿作用研究进展. 岩石 学报, 2008, 24: 1665-1678]

16 Xie G, Mao J, Li R, et al. Geochemistry and Nd-Sr isotopic studies of Late Mesozoic granitoids in the southeastern Hubei Province, Middle- 
Lower Yangtze River belt, Eastern China: Petrogenesis and tectonic setting. Lithos, 2008, 104: 216-230

17 Mao J, Xie G, Duan C, et al. A tectono-genetic model for porphyry-skarn-stratabound $\mathrm{Cu}-\mathrm{Au}-\mathrm{Mo}-\mathrm{Fe}$ and magnetite-apatite deposits along the Middle-Lower Yangtze River Valley, Eastern China. Ore Geol Rev, 2011, 43: 294-314

18 Zhou T F, Fan Y, Wang S W, et al. Metallogenic regularity and metallogenic model of the Middle-Lower Yangtze River Valley Metallogenic Belt (in Chinese). Acta Petrol Sin, 2017, 33: 3353-3372 [周涛发, 范裕, 王世伟, 等. 长江中下游成矿带成矿规律和成矿模式. 岩石学报, 2017, 33: 3353-3372]

19 Wang X L, Zhou J C, Griffin W L, et al. Detrital zircon geochronology of Precambrian basement sequences in the Jiangnan orogen: Dating the assembly of the Yangtze and Cathaysia Blocks. Precambrian Res, 2007, 159: 117-131

20 Shu L, Charvet J. Kinematics and geochronology of the Proterozoic Dongxiang-Shexian ductile shear zone: With HP metamorphism and ophiolitic melange (Jiangnan Region, South China). Tectonophysics, 1996, 267: 291-302

21 Charvet J, Shu L, Shi Y, et al. The building of South China: Collision of Yangzi and Cathaysia blocks, problems and tentative answers. J Southeast Asian Earth Sci, 1996, 13: 223-235

22 Sun J, Shu L, Santosh M, et al. Precambrian crustal evolution of the central Jiangnan Orogen (South China): Evidence from detrital zircon U-Pb ages and Hf isotopic compositions of Neoproterozoic metasedimentary rocks. Precambrian Res, 2018, 318: 1-24

23 Wan H Z, Liu Z Q, Liu S B, et al. LA-ICP-MS zircon U-Pb dating of granodioritic porphyry located Zhuxi copper-tungsten mine in northeast Jiangxi and its geological significance (in Chinese). Rock Miner Anal, 2015, 34: 494-502 [万浩章, 刘战庆, 刘善宝, 等. 赣东北朱溪铜铇矿区花 岗闪长斑岩LA-ICP-MS锆石U-Pb定年及地质意义. 岩矿测试, 2015, 34: 494-502]

24 Mao J W, Ouyang H G, Song S W, et al. Geology and metallogeny of tungsten and tin deposits in China. SEG Spec Publ, 2019, 22: 411-482 树. 华南构造演化的基本特征. 地质通报, 2012, 31: 1035-1053

26 Maruyama S, Isozaki Y, Kimura G, et al. Paleogeographic maps of the Japanese Islands: Plate tectonic synthesis from 750 Ma to the present. Isl Arc, 1997, 6: 121-142

27 Mao J, Pirajno F, Cook N. Mesozoic metallogeny in East China and corresponding geodynamic settings-An introduction to the special issue. Ore Geol Rev, 2011, 43: 1-7

28 Wang X L, Zhou J C, Wan Y S, et al. Magmatic evolution and crustal recycling for Neoproterozoic strongly peraluminous granitoids from southern China: Hf and O isotopes in zircon. Earth Planet Sci Lett, 2013, 366: 71-82

29 Li J M, Li Y M, Lou F S, et al. A “five-storey” style quartz vein wolframite deposit in northern Jiangxi Province: The discovery of the Dongping wolframite deposit and its geological significance (in Chinese). Acta Geosci Sin, 2016, 37: 379-384 [李吉明, 李永明, 楼法生, 等. 赣北发现“五 层楼”式石英脉型黑铇矿矿床——东坪黑铇矿矿床的发现及其地质意义. 地球学报, 2016, 37: 379-384]

30 Yang X H, Hu W J, Zhong Q H, et al. Geological characteristics, ore controlling factors and prospecting indicators of Dongping quartz vein type wolframite deposit in Jiangxi (in Chinese). J Jilin Univ (Earth Sci Ed), 2019, 49: 1301-1316 [杨细浩, 胡文洁, 钟起泓, 等. 江西东坪石英脉型黑 铇矿矿床地质特征、控矿因素及找矿标志. 吉林大学学报(地球科学版), 2019, 49: 1301-1316]

31 Nie L Q, Zhou T F, Zhang Q M, et al. Trace elements and Sr-Nd isotopes of scheelites: Implications for the skarn tungsten mineralization of the Donggushan deposit, Anhui Province, China (in Chinese). Acta Petrol Sin, 2017, 33: 3518-3530 [聂利青, 周涛发, 张千明, 等. 安徽东顾山铇矿 床白铇矿主微量元素和Sr-Nd同位素特征及其对成矿作用的指示. 岩石学报, 2017, 33: 3518-3530]

32 Yan D R, Deng X D, Hu H, et al. U-Pb age and petrogenesis of the Ruanjiawan granodiorite pluton and Xiniushan granodiorite porphyry, Southeast Hubei Province: Implications for Cu-Mo mineralization (in Chinese). Acta Petrol Sin, 2012, 28: 3373-3388 [颜代蓉, 邓晓东, 胡浩, 等. 鄂东南地区阮家湾和犀牛山花岗闪长岩的时代、成因及成矿和找矿意义. 岩石学报, 2012, 28: 3373-3388]

$33 \mathrm{Hu} \mathrm{Z} \mathrm{H}$, Wang X G, Chen G H, et al. Characteristics of Tongjiangling copper-tungsten deposit in Jiangxi and its prospecting significance (in Chinese). China Tungsten Ind, 2018, 33: 15-20 [胡正华, 王先广, 陈国华, 等. 江西通江岭铜铇矿床特征及其找矿意义. 中国铇业, 2018, 33: 15-20]

34 Wang X G, Hu Z H, Huang Q Y, et al. Zircon U-Pb age of ore-forming magmatic rocks in the Tongjiangling coppertungsten deposit in the Jiurui ore concentration area and its significance (in Chinese). Geol China, 2019, 46: 832-840 [王先广, 胡正华, 黄秋芸, 等. 九瑞矿集区通江岭铜铇 矿成矿岩浆岩锆石U-Pb 年龄及意义. 中国地质, 2019, 46: 832-840]

35 Huang L C, Jiang S Y. Zircon U-Pb geochronology, geochemistry and petrogenesis of the porphyric-like muscovite granite in the Dahutang tungsten deposit, Jiangxi Province (in Chinese). Acta Petrol Sin, 2012, 28: 3887-3900 [黄兰椿, 蒋少涌. 江西大湖塘铇矿床似斑状白云母花岗 岩锆石U-Pb年代学、地球化学及成因研究. 岩石学报, 2012, 28: 3887-3900]

36 Huang L C, Jiang S Y. Geochronology, geochemistry and petrogenesis of the tungsten-bearing porphyritic granite in the Dahutang tungsten deposit, Jiangxi Province (in Chinese). Acta Petrol Sin, 2013, 29: 4323-4335 [黄兰椿, 蒋少涌. 江西大湖塘富铇花岗斑岩年代学、地球化学特 征及成因研究. 岩石学报, 2013, 29: 4323-4335]

37 Mao Z, Cheng Y, Liu J, et al. Geology and molybdenite Re-Os age of the Dahutang granite-related veinlets-disseminated tungsten ore field in the 
Jiangxin Province, China. Ore Geol Rev, 2013, 53: 422-433

38 Mao Z, Liu J, Mao J, et al. Geochronology and geochemistry of granitoids related to the giant Dahutang tungsten deposit, middle Yangtze River region, China: Implications for petrogenesis, geodynamic setting, and mineralization. Gondwana Res, 2015, 28: 816-836

$39 \mathrm{Fu} \mathrm{J} \mathrm{Z,} \mathrm{Xu} \mathrm{S} \mathrm{F,} \mathrm{Wang} \mathrm{M} \mathrm{H,} \mathrm{et} \mathrm{al.} \mathrm{Geologic} \mathrm{features} \mathrm{and} \mathrm{ore-controlling} \mathrm{factors} \mathrm{of} \mathrm{Dongyuan} \mathrm{tungsten} \mathrm{and} \mathrm{molybdenum} \mathrm{deposit,} \mathrm{Anhui} \mathrm{Province}$ (in Chinese). Miner Explor, 2011, 2: 501-511 [傅建真, 徐生发, 汪明辉, 等. 安徽东源铇钼矿床地质特征及控矿因素. 矿产勘查, 2011, 2: 501511]

40 Wu S, Sun W, Wang X. A new model for porphyry W mineralization in a world-class tungsten metallogenic belt. Ore Geol Rev, 2019, 107: 501512

41 Song S W, Mao J W, Zhu Y F, et al. Partial-melting of fertile metasedimentary rocks controlling the ore formation in the Jiangnan porphyry-skarn tungsten belt, South China: A case study at the giant Zhuxi W-Cu skarn deposit. Lithos, 2018, 304-307: 180-199

42 Song S W, Mao J W, Xie G Q, et al. The formation of the world-class Zhuxi scheelite skarn deposit: Implications from the petrogenesis of scheelite bearing anorthosite. Lithos, 2018, 312-313: 153-170

43 Song S, Mao J, Xie G, et al. In situ LA-ICP-MS U-Pb geochronology and trace element analysis of hydrothermal titanite from the giant Zhuxi W (Cu) skarn deposit, South China. Miner Depos, 2019, 54: 569-590

44 He X R, Chen G H, Liu J G, et al. On the copper-tungsten prospecting orientation in Zhuxi region (in Chinese). China Tungsten Ind, 2011, 26: 914 [何细荣, 陈国华, 刘建光, 等. 江西景德镇朱溪地区铜铇多金属矿找矿方向. 中国铇业, 2011, 26: 9-14]

45 Dai P, Mao J, Wu S, et al. Multiple dating and tectonic setting of the Early Cretaceous Xianglushan W deposit, Jiangxi Province, South China. Ore Geol Rev, 2018, 95: 1161-1178

$46 \mathrm{Su}$ Q W, Mao J W, Wu S H, et al. Geochronology and geochemistry of the granitoids and ore-forming age in the Xiaoyao tungsten polymetallic skarn deposit in the Jiangnan Massif tungsten belt, China: Implications for their petrogenesis, geodynamic setting, and mineralization. Lithos, 2018, 296-299: 365-381

$47 \mathrm{Xu} \mathrm{B}$, Jiang S Y, Luo L, et al. Origin of the granites and related Sn and Pb-Zn polymetallic ore deposits in the Pengshan district, Jiangxi Province, South China: Constraints from geochronology, geochemistry, mineral chemistry, and Sr-Nd-Hf-Pb-S isotopes. Miner Depos, 2017, 52: 337-360 Wai-Pan Ng S, Whitehouse M J, Searle M P, et al. Petrogenesis of Malaysian granitoids in the Southeast Asian tin belt: Part 2. U-Pb zircon geochronology and tectonic model. Geol Soc Am Bull, 2015, 127: 1238-1258

49 Cao J, Yang X, Du G, et al. Genesis and tectonic setting of the Malaysian Waterfall granites and tin deposit: Constraints from LA-ICP (MC)-MS zircon U-Pb and cassiterite dating and Sr-Nd-Hf isotopes. Ore Geol Rev, 2020, 118: 103336

50 Mao J W, Xie G Q, Pirajno F, et al. Late Jurassic-Early Cretaceous granitoid magmatism in Eastern Qinling, central-eastern China: SHRIMP zircon U-Pb ages and tectonic implications. Aust J Earth Sci, 2010, 57: 51-78

51 Bao Z, Wang C Y, Zhao T, et al. Petrogenesis of the Mesozoic granites and Mo mineralization of the Luanchuan ore field in the East Qinling Mo mineralization belt, Central China. Ore Geol Rev, 2014, 57: 132-153

52 Fonteilles M, Soler P, Demange M, et al. The scheelite skarn deposit of Salau (Ariege, French Pyrenees). Econ Geol, 1989, 84: 1172-1209

53 Noble S R, Spooner E T C, Harris F R. The Logtung large tonnage, low-grade W (scheelite)-Mo porphyry deposit, south-central Yukon Territory. Econ Geol, 1984, 79: 848-868

54 Parrish I S, Tully J V. Porphyry tungsten zones at Mt Pleasant, New Brunswick. CIM Bull, 1978, 71: 93-100

55 Sinclair W D. Porphyry deposits. In: Goodfellow W D, ed. Mineral Deposits of Canada: A Synthesis of Major Deposit-Types, District Metallogeny, the Evolution of Geological Provinces, and Exploration Methods. Newfoundland: Geological Association of Canada, Mineral Deposits Division, Special Publication No. 5, 2007. 223-243

56 Man F S, Wang X S. Isotopic geochronolgy of the Yangchuling porphyry tungsten-molybdenum deposit. Geol Miner Resour, 1988, 1: 61-66

57 Tan Y J. Metallogenic mechanism of the Lianhuashan porphyry W deposit (in Chinese). Sci China Ser B, 1985, 6: 563-570 [谭运金. 莲花山斑岩 铇矿床的成矿机理. 中国科学B辑, 1985, 6: 563-570]

58 Tan Y J. Geology and geochemistry of the Lianhuashan porphyry W deposit (in Chinese). Miner Resour Geol, 1986, 1: 19-26 [谭运金. 莲花山斑 岩铇矿床蚀变作用的地质地球化学. 矿产与地质, 1986, 1: 19-26]

59 So C S, Rye D M, Shelton K L. Carbon, hydrogen, oxygen, and sulfur isotope and fluid inclusion study of the Weolag tungsten-molybdenum deposit, Republic of Korea; fluid histories of metamorphic and ore-forming events. Econ Geol, 1983, 78: 1551-1573

60 So C S, Shelton K L, Seidemann D E, et al. The Dae Hwa tungsten-molybdenum mine, Republic of Korea; a geochemical study. Econ Geol, 1983, 78: $920-930$

61 Gu J Y. The Characteristics of dominant porphyry tungsten deposits of China (in Chinese). Miner Resour Geol, 1988, 2: 13-21 [古菊英. 中国主 要斑岩铇矿床特征. 矿产与地质, 1988, 2: 13-21]

62 Tan Y J. Porphyry W deposit (in Chinese). Geol Geochem, 1979, 12: 1-7 [谭运金. 斑岩铇矿床. 地质地球化学, 1979, 12: 1-7]

63 Davis W J, Williams-Jones A E. A fluid inclusion study of the porphyry-greisen, tungsten-molybdenum deposit at Mount Pleasant, New 
Brunswick, Canada. Miner Depos, 1985, 20: 94-101

64 Rusk B G, Reed M H, Dilles J H. Fluid inclusion evidence for magmatic-hydrothermal fluid evolution in the porphyry copper-molybdenum deposit at Butte, Montana. Econ Geol, 2008, 103: 307-334

65 Zhao M C, Yu X C, Zhang Y F, et al. Conceptual model for genesis of mineralized fissures in porphyry deposits and its geological significance (in Chinese). Miner Depos, 2020, 39: 19-41 [赵茂春, 余先川, 张翼飞, 等. 斑岩型矿床容矿裂隙成因的几种概念模型及其意义. 矿床地质, 2020, 39: 19-41]

66 Tornos F, Galindo C, Crespo J L, et al. Geochemistry and origin of calcic tungsten-bearing skarns, Los Santos, Central Iberian Zone, Spain. Can Miner, 2008, 46: 87-109

67 Zhu J C, Li R K, Li F C, et al. Topaz-albite granites and rare-metal mineralization in the Limu District, Guangxi, southeast China. Miner Depos, 2001, 36: 393-405

68 Breiter K, Škoda R. Vertical zonality of fractionated granite plutons reflected in zircon chemistry: The Cínovec A-type versus the Beauvoir S-type suite. Geol Carpath, 2012, 63: 383-398

69 Johannes W, Holtz F. Petrogenesis and Experimental Petrology of Granitic Rocks. Berlin: Springer, 1996

70 Tuttle O F, Bowen N L. Origin of granite in the light of experimental studies in the system $\mathrm{NaAlSi}_{3} \mathrm{O}_{8}-\mathrm{KAlSi}_{3} \mathrm{O}_{8}-\mathrm{SiO}_{2}-\mathrm{H}_{2} \mathrm{O}$. Geol Soc Am Mem, 1958, 74: 1-146

71 Stewart D B, Roseboom E H. Lower temperature terminations of the three-phase region plagioclase-alkali feldspar-liquid. J Petrol, 1962, 3: 280315

72 Panjasawatwong Y, Danyushevsky L V, Crawford A J, et al. An experimental study of the effects of melt composition on plagioclase-melt equilibria at 5 and 10 kbar: Implications for the origin of magmatic high-An plagioclase. Contr Miner Petrol, 1995, 118: 420-432

73 Newberry R J, Einaudi M T. Tectonic and geochemical setting of tungsten skarn mineralization in the Cordillera. Arizona Geol Soc Digest, 1981, 14: $99-111$

74 Meinert L D, Dipple G M, Nicolescu S. World skarn deposits. In: Hedenquist J W, Thompson J F H, Goldfarb R J, et al., eds. Economic Geology 100th Anniversary Volume. Littleton: Society of Economic Geologists, Inc., 2005. 299-336

75 Ishihara S. The granitoid series and mineralization. Econ Geol, 1981, 75: 458-484

76 Patiño Douce A E, Harris N. Experimental constraints on Himalayan anatexis. J Petrol, 1998, 39: 689-710

$77 \mathrm{Xu} \mathrm{K} \mathrm{Q,} \mathrm{Hu} \mathrm{S} \mathrm{X,} \mathrm{Sun} \mathrm{M} \mathrm{Z,} \mathrm{et} \mathrm{al.} \mathrm{On} \mathrm{the} \mathrm{genetic} \mathrm{series} \mathrm{of} \mathrm{granites,} \mathrm{as} \mathrm{exemplified} \mathrm{by} \mathrm{the} \mathrm{Mesozoic} \mathrm{granites} \mathrm{of} \mathrm{South} \mathrm{China} \mathrm{(in} \mathrm{Chinese).} \mathrm{Acta}$ Geol Sin, 1983, 2: 3-14 [徐克勤, 胡受奚, 孙明志, 等. 论花岗岩的成因系列——以华南中生代花岗岩为例. 地质学报, 1983, 2: 3-14]

78 Hua R M, Chen P R, Zhang W L, et al. Metallogenic system related to Mesozoic and Genozoic granitoids in South China (in Chinese). Sci China Earth Sci, 2003, 33: 335-343 [华仁民, 陈培荣, 张文兰, 等. 华南中、新生代与花岗岩类有关的成矿系统. 中国科学: 地球科学, 2003, 33: 335-343]

79 Mao J W, Xie G Q, Guo C L, et al. Large-scale tungsten-tin mineralization in the Nanling region, South China: Metallogenic ages and corresponding geodynamic processes (in Chinese). Acta Petrol Sin, 2007, 23: 2329-2338 [毛景文, 谢桂青, 郭春丽, 等. 南岭地区大规模钨锡多 金属成矿作用: 成矿时限及地球动力学背景. 岩石学报, 2007, 23: 2329-2338]

80 Pitcairn I K, Teagle D A H, Craw D, et al. Sources of metals and fluids in orogenic gold deposits: Insights from the Otago and Alpine Schists, New Zealand. Econ Geol, 2006, 101: 1525-1546

81 Mao J W, Chen Y B, Chen M H, et al. Major types and time-space distribution of Mesozoic ore deposits in South China and their geodynamic settings. Miner Depos, 2013, 48: 267-294

82 Romer R L, Kroner U. Sediment and weathering control on the distribution of Paleozoic magmatic tin-tungsten mineralization. Miner Depos, 2015, 50: 327-338

83 Petford N, Cruden A R, McCaffrey K J W, et al. Granite magma formation, transport and emplacement in the Earth's crust. Nature, 2000, 408: $669-673$

84 Nesbitt B E. Gold deposit continuum: A genetic model for lode Au mineralization in the continental crust. Geology, 1988, 16: 1044-1048

85 Shi D, Lü Q, Xu W, et al. Crustal structure beneath the middle-lower Yangtze metallogenic belt in East China: Constraints from passive source seismic experiment on the Mesozoic intra-continental mineralization. Tectonophysics, 2013, 606: 48-59

86 Kavanagh J L, Menand T, Sparks R S J. An experimental investigation of sill formation and propagation in layered elastic media. Earth Planet Sci Lett, 2006, 245: 799-813

87 Zhang Z J, Zhang X, Badal J. Composition of the crust beneath southeastern China derived from an integrated geophysical data set. J Geophys Res, 2008, 113: 540-549

88 Liu Y J, Li Z L, Ma D S. Geochemical study of tungsten-bearing structures in South China (in Chinese). Sci China Ser B, 1982, 12: 939-950 [刘] 英俊, 李兆麟, 马东升. 华南含铇建造的地球化学研究. 中国科学B辑, 1982, 12: 939-950]

89 Rudnick R, Gao S. Composition of the continental crust. Treat Geochem, 2003, 3: 1-64 
90 Mitchell A H G, Garson M S. Mineral Deposits and Global Tectonic Settings. London: Academic Press, 1981. 405

91 Sawkins F J. Metal Deposits in Relation to Plate Tectonics. Berlin: Springer, 1984

92 Seltmann R, Kampf H, Moller P. Metallogenesis in Collisional Orogens. Postdam: GeoForschungs Zentrum Postdam, 1994. 1-434

93 Forster H J, Tischendorf G, Trumbull R B, et al. Late-collisional granites in the variscan erzgebirge, Germany. J Petrol, 1999, 40: 1613-1645

94 Lehmann B. Metallogeny of the Central Andes: Geotectonic framework and geochemical evolution of porphyry system in Bolivia and Chile during the last 40 Million years. In: Khanchuk A I, Gonevchuk G A, Mitrokhin A N, et al., eds. Metallogny of the Pacific Northwest: Tectonics, Magmatism and Metallogeny of Active Continental Margins. Vladivostok: Dalnauka, 2004. 118-122

95 Deckart K, Silva W, Spröhnle C, et al. Timing and duration of hydrothermal activity at the Los Bronces porphyry cluster: An update. Miner Depos, 2014, 49: 535-546

96 Mao J W, Xie G Q, Yuan S D, et al. Current research progress and future trends of porphyry-skarn copper and granite-related tin polymetallic deposits in the Circum Pacific metallogenic belts. Acta Petrol Sin, 2018, 34: 2501-2517

97 Zhu R X, Fan H R, Li J W, et al. Decratonic gold deposits (in Chinese). Sci China Earth Sci, 2015, 58: 1523-1537 [朱日祥, 范宏瑞, 李建威, 等. 克拉通破坏型金矿床. 中国科学: 地球科学, 2015, 58: 1523-1537]

98 Zhou T F, Fan Y, Yuan F, et al. Geochronology and significance of volcanic rocks in the Ning-Wu Basin of China (in Chinese). Sci China: Earth Sci, 2011, 54: 185-196 [周涛发, 范裕, 袁峰, 等. 宁芜(南京-芜湖)盆地火山岩的年代学及其意义. 中国科学: 地球科学, 2011, 54: 185-196]

99 Duan Z, Xing G F, Yu M G, et al. Time sequence and geological process of late Mesozoic volcanic activities in the area of Zhejiang-Fujian boundary (in Chinese). Geol Rev, 2013, 59: 454-469 [段政, 邢光福, 余明刚, 等. 浙闽边界区晚中生代火山作用时序与过程分析. 地质论评, 2013, 59: 454-469]

100 Liu L, Xu X, Zou H. Episodic eruptions of the Late Mesozoic volcanic sequences in southeastern Zhejiang, SE China: Petrogenesis and implications for the geodynamics of paleo-Pacific subduction. Lithos, 2012, 154: 166-180

101 Su H M, Mao J W, He X R, et al. Timing of the formation of the Tianhuashan Basin in northern Wuyi as constrained by geochronology of volcanic and plutonic rocks. Sci China Earth Sci, 2013, 56: 940-955

102 Mao J, Pirajno F, Lehmann B, et al. Distribution of porphyry deposits in the Eurasian continent and their corresponding tectonic settings. J Asian Earth Sci, 2014, 79: 576-584

103 van der Voo R, Spakman W, Bijwaard H. Mesozoic subducted slabs under Siberia. Nature, 1999, 397: 246-249

104 Huang J, Zhao D. High-resolution mantle tomography of China and surrounding regions. J Geophys Res, 2006, 111: B09305

105 Lee C T, Yin Q, Rudnick R L, et al. Preservation of ancient and fertile lithospheric mantle beneath the southwestern United States. Nature, 2001, 411: 69-73

106 Lehmann B. Metallogeny of Tin. Berlin: Springer, 1990. 211

107 Jiang S Y, Peng N J, Huang L C, et al. Geological characteristic and ore genesis of the giant tungsten deposits from the Dahutang ore-concentrated district in northern Jiangxi Province (in Chinese). Acta Petrol Sin, 2015, 31: 639-655 [蒋少涌,彭宁俊, 黄兰椿, 等. 赣北大湖塘矿集区超大型 铇矿地质特征及成因探讨. 岩石学报, 2015, 31: 639-655]

108 Song G, Qin K, Li G, et al. Geochronologic and isotope geochemical constraints on magmatism and associated W-Mo mineralization of the Jitoushan W-Mo deposit, middle-lower Yangtze Valley. Int Geol Rev, 2012, 54: 1532-1547

109 Li C, Jiang Y, Xing G, et al. Two periods of skarn mineralization in the baizhangyan W-Mo deposit, southern Anhui Province, Southeast China: Evidence from zircon U-Pb and molybdenite Re-Os and sulfur isotope data. Resour Geol, 2015, 65: 193-209

110 Mahood G A, Cornejo P C. Evidence for ascent of differentiated liquids in a silicic magma chamber found in a granitic pluton. Earth Environ Sci Trans R Soc Edinb, 1992, 83: 63-69

111 Sillitoe R H. Porphyry copper systems. Econ Geol, 2010, 105: 3-41

112 Heinrich C A, Driesner T, Stefánsson A, et al. Magmatic vapor contraction and the transport of gold from the porphyry environment to epithermal ore deposits. Geology, 2004, 32: 761-764

$113 \mathrm{Lu} \mathrm{Y,} \mathrm{Chen} \mathrm{B} \mathrm{C,} \mathrm{Cao} \mathrm{B} \mathrm{G.} \mathrm{The} \mathrm{distribution} \mathrm{of} \mathrm{Alteration} \mathrm{in} \mathrm{Yangchuling} \mathrm{porphyry} \mathrm{type} \mathrm{tungsten} \mathrm{and} \mathrm{molybdenum} \mathrm{deposit,} \mathrm{Jiangxi} \mathrm{Province} \mathrm{(in}$ Chinese). J Miner Petrol, 1986, 6: 102-110 [卢宇, 陈炳才, 曹帮功. 江西阳储岭班岩铇钼矿床蚀变统计分带. 矿物岩石, 1986, 6: 102-110]

114 Mo M Z. A preliminary study on alteration zoning of the Yangchuling porphyry W-Mo deposit and its relationship to mineralization (in Chinese). Miner Depos, 1988, 7: 51-58 [莫名浈. 阳储岭斑岩铇锄矿床蚀变分带特征及与成矿作用关系的初步研究. 矿床地质, 1988, 7: 51-58]

\section{补充材料}

图S1 江南铇矿带铇矿床成矿时代和有关花岗质岩石的成岩时代直方图 
图S2 江南铇矿带成矿相关岩体

图S3 江南铇矿带成矿相关岩体的 $10000 \mathrm{Ga} / \mathrm{Al}-\mathrm{Zr}$ 图解与 $\mathrm{P}_{2} \mathrm{O}_{5}-\mathrm{SiO}_{2}$ 图解

图S4 江南铇矿带与成矿有关岩体的稀土元素球粒陨石标准化分布型式图和微量元素原始地幔标准化蛛网图

图S5 岩浆结晶过程释放多批次流体形成岩体内部多旋回矿体成矿过程图解

表S1 江南古陆铇矿带矿床地质特征信息

本文以上补充材料见网络版csb.scichina.com. 补充材料为作者提供的原始数据, 作者对其学术质量和内容负责. 


\title{
The world-class Jiangnan tungsten belt: Geological characteristics, metallogeny, and ore deposit model
}

\author{
Jingwen Mao ${ }^{1,2^{*}}$, Shenghua $\mathrm{Wu}^{1}$, Shiwei Song ${ }^{1}$, Pan Dai ${ }^{3}$, Guiqing Xie ${ }^{1}$, Qiangwei Su ${ }^{1}$, Peng Liu ${ }^{4}$, \\ Xianguang Wang ${ }^{5}$, Zhongzhen $\mathrm{Yu}^{6}$, Xiangyun $\mathrm{Chen}^{6} \&$ Weixin Tang ${ }^{6}$ \\ ${ }^{1}$ Key Laboratory of Metallogeny and Mineral Assessment (Ministry of Natual Resources), Institute of Mineral Resources, Chinese Academy of Geo- \\ logical Sciences, Beijing 100037, China; \\ ${ }^{2}$ College of Geosciences, Hebei GEO University, Shijiazhuang 050031, China; \\ ${ }^{3}$ School of Resources and Environmental Engineering, Shandong University of Technology, Zibo 255000, China; \\ ${ }^{4}$ School of Earth Science and Resources, Chang'an University, Xi'an 710054, China; \\ ${ }^{5}$ Jiangxi Geological Prospecting Fund Management Center, Nanchang 330025, China; \\ ${ }^{6}$ Jiangxi Bureau of Geology and Mineral Exploration and Development, Nanchang 330002, China \\ * Corresponding author, E-mail: jingwenmao@263.net
}

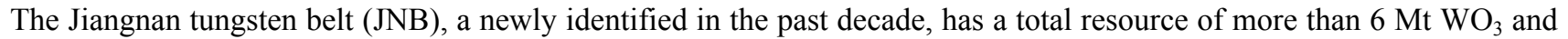
still has a good potential for further prospecting. The JNB, located along the Jiangnan Massif (JM) and its eastern extensional areas, is adjacent to and parallel with the Middle-Lower Yangtze River porphyry-skarn Cu-Mo-Au-Fe belt (MLYRB) at north. Both JNB and MLYRB have the same mineralization periods, i.e., 150-135 and 130-125 Ma.

The tungsten mineralization in JNB developed at the proximal contact of granite plutons, whereas the $\mathrm{Pb}-\mathrm{Zn} \pm \mathrm{Cu}$ veins occurs at the distal areas, exhibiting an obvious zoning in space. Apart from the Dongping quartz vein wolframite deposit, the other $\mathrm{W}$ deposits in the JNB belong to porphyry and skarn types. The Zhuxi scheelite skarn deposit with $3.44 \mathrm{Mt}$ of $\mathrm{WO}_{3}$ is the largest one over the world. Meanwhile, the exploration of the Dahutang super-large, and Dongyuan and Yangchuling large porphyry $\mathrm{W}$ deposits has proven the porphyry is a new major $\mathrm{W}$ type except for both skarn and quartz vein types which were recognized before. Moreover, it is interesting to find unusual scheelite-bearing anorthosite and albitite dikes, which cut through the skarn ores in the Zhuxi deposit area. The scheelite-bearing albitite is proposed to crystallize from Al-, Si-, P-, W-, and F-rich residual magma whereas the scheelite-bearing anorthosite formed when the residual magma was contaminated by pure limestone in a reducing environment.

The granitoids associated with $\mathrm{W}$ deposits and W-Mo deposits in the JNB are biotite monzonite and granodiorite, respectively. According to the petrology, geochemistry and major accessory minerals, the ore-related granitoids can be recognized as $\mathrm{S}$ type (or ilmenite series) with peraluminous nature and I type (or magnetite series) with metaluminous nature. Geochemical and Sr-Nd-Hf isotopic data indicate the $\mathrm{W}$ deposits-related granitoids were derived from the remelting of the Neoproterozoic phyllite and slate and the W-Mo deposits-related granitoids were also derived from the same strata but with input of mantle materials. According to the sources of granitoids and the skarn mineral assemblages as well as mineral chemistry it can be recognized as reduced $\mathrm{W}$ and the oxidized W-Mo deposits. Usually the reduced W deposit appears as large and super-large scale, such as the Zhuxi and Dahutang whereas the oxidized W-Mo as relatively smaller.

A tectonic model is suggested to explain the two periods of mineralization in both JNB and MLYRB, which are corresponding to oblique subduction of Izanagi plate in 150-135 Ma at quite low angle and the extension tectonic regime of post-subduction at 130-125 Ma, respectively. The porphyry-skarn Cu-Mo-Au-Fe system in early period and apatitemagnetite system in late period along MLYRB are related to the granitoids derived from the slab subducted slab and the stagnant slab whereas tow periods of porphyry-skarn as well as quartz vein type W(Sn) deposits are associated with the granitoids which were remelted from the Neoproterozoic phyllite deduced from mantle underplated. Moreover, a deposit model is set up for the relationship among the porphyry-skarn $\mathrm{W}$ and $\mathrm{W}-\mathrm{Mo}$, and distal $\mathrm{Pb}-\mathrm{Zn}-\mathrm{Ag} \pm \mathrm{Cu}$ veins, which can be referenced for the further prospecting in JNB and the regions with similar tectonic setting.

tungsten deposit, porphyry-skarn type, metallogenetic regularity, mineral deposit model

doi: 10.1360/TB-2020-0370 